\title{
A 95-Year-Old Concrete Arch Bridge: From Materials Characterization to Structural Analysis
}

\author{
Andrzej Ambroziak * (D) and Maciej Malinowski \\ Faculty of Civil and Environmental Engineering, Gdansk University of Technology, 11/12 Gabriela \\ Narutowicza Street, 80-233 Gdańsk, Poland; maciej.malinowski@pg.edu.pl \\ * Correspondence: ambrozan@pg.edu.pl; Tel.: +48-58-347-2447
}

Citation: Ambroziak, A.;

Malinowski, M. A 95-Year-Old

Concrete Arch Bridge: From

Materials Characterization to

Structural Analysis. Materials 2021, 14,

1744. https://doi.org/10.3390/

ma14071744

Academic Editors: Eva

O.L. Lantsoght and F. Pacheco Torgal

Received: 6 March 2021

Accepted: 30 March 2021

Published: 1 April 2021

Publisher's Note: MDPI stays neutral with regard to jurisdictional claims in published maps and institutional affiliations.

Copyright: (c) 2021 by the authors. Licensee MDPI, Basel, Switzerland. This article is an open access article distributed under the terms and conditions of the Creative Commons Attribution (CC BY) license (https:// creativecommons.org/licenses/by/ $4.0 /)$.

\begin{abstract}
The structural analysis of a 95-year-old concrete arch bridge located in Jagodnik (Poland) is performed in this paper, in order to check its behavior under today's traffic loads. The mechanical properties of both the concrete and the reinforcement are investigated by testing cores and bar stubs extracted from the bridge. Structural analysis confirms that the bridge meets today's load requirements in terms of bearing capacity, serviceability state, and that the adopted structural improvements (a new deck slab on top of the existing structure and a layer of mortar to protect the surface of the old concrete) are effective. In this way, the 95-year-old arch bridge was given a new life. The structural improvements show how combining numerical modelling and laboratory tests can contribute to the preservation of an old - though fairly simple-and valuable structure, otherwise destined to demolition, with both environmental and economic benefits.
\end{abstract}

Keywords: structural analysis; bridge engineering; reinforced concrete; mechanical properties

\section{Introduction}

Arch bridges are one of the most popular types of bridges. At present, there are over 40 concrete arch bridges in the world with a span of greater than $200 \mathrm{~m} \mathrm{[1]}$. Concrete application in the development of arch bridges has a long and interesting history [2]. In most countries, there are old bridges that require maintenance, renovation, or reconstruction [3]. In the literature, it is possible to find many interesting investigations related to the process of testing and repairing old concrete bridges [4-15] or to the structural analysis of old bridges [16-22]. Reconstruction and renovation of old bridge structures and adaptation to new traffic loads are complex issues often requiring not only the experience of civil engineers, but also that of the scientific community. Before dealing with the technical conditions and bearing capacity of any given bridge structure, a detailed inspection is a must. The code provisions concerning the original materials like mechanical, chemical, and also physical properties are required for proper assessment of conditions of old structures to reflect their real technical conditions. The scope of material tests should be adapted to the specificity of the construction and location of the bridge structure. The design team often faces the problem of limited or even lacking original documentation. It is then necessary to make a detailed inspection which is instrumental in defining the scope of the reconstruction or repair process, as well as in formulating a numerical model. New technics, like laser scanning, photogrammetry techniques and ground penetrating radar [23-29], have been increasingly used in terms of monitoring, inventory control and structural inspection. New tools and techniques are very helpful in the technical and theoretical assessment of old bridge structures.

The present study is aimed at the structural analysis of the 95-year-old concrete arch bridge based on mechanical properties measured by means of laboratory tests. Structural analysis was a part of an expert opinion, required to check whether the old arch bridge has an adequate bearing capacity face to today's traffic loads, in order to extend its service 
life. The present paper supplements and extends the investigations performed by Ambroziak et al. [30] on the design stage. In the present paper, new concrete samples taken from the old concrete arch bridge during its reconstruction were tested in a laboratory and the results of the tests on the original steel reinforcement are presented. The results about the internal forces under design loads are determined and the maximum stresses in both the concrete and the reinforcement are evaluated and compared with the design stresses, and the displacements are checked with reference to those specified for the service limit state. The paper provides scientists, engineers, and designers the example of structural analysis results and experimental assessment of the 95-year-old concrete arch bridge.

\section{Materials and Methods}

The old bridge investigated (see Figure 1) is an arch bridge built in 1925 close to the city of Elblag (village Jagodnik in Poland) above the Kumiel river. Karl Metzger \& Co. building company [31] was responsible for the construction of the bridge, which consists of a reinforced-concrete slab monolithically connected to a reinforced-concrete arch with a span equal to $12.95 \mathrm{~m}$.

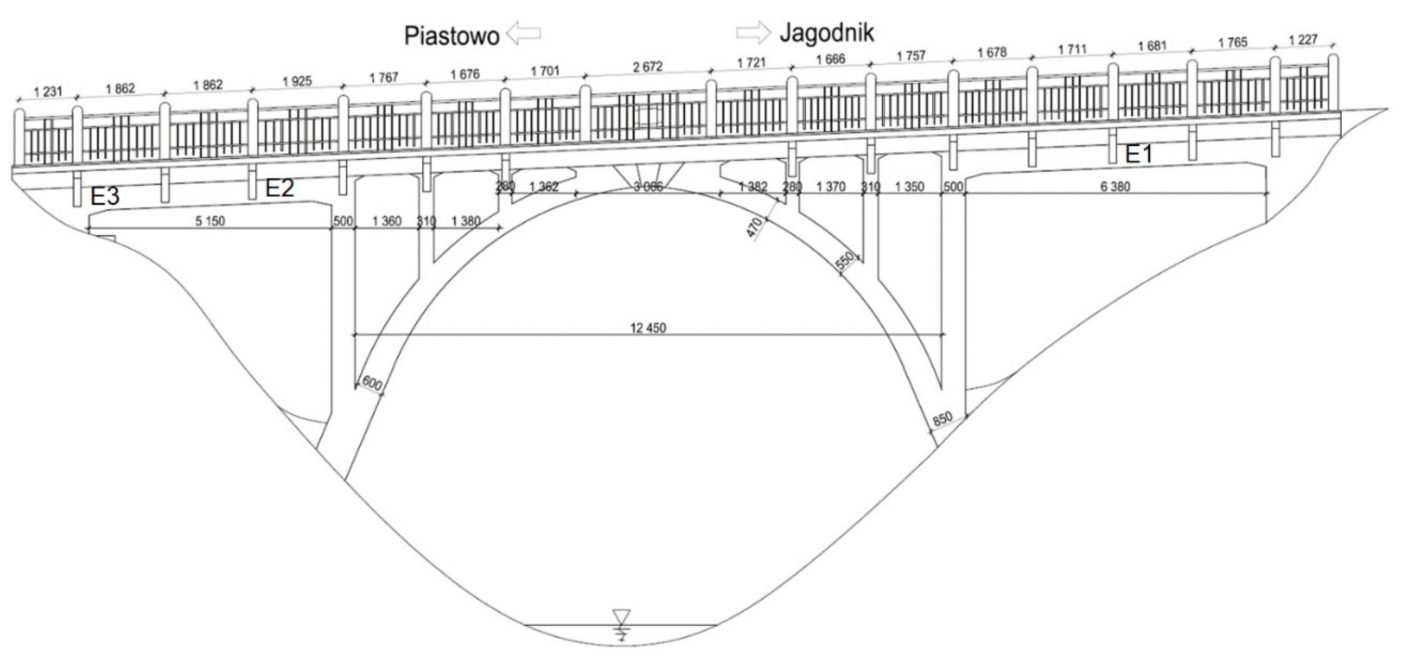

(a)

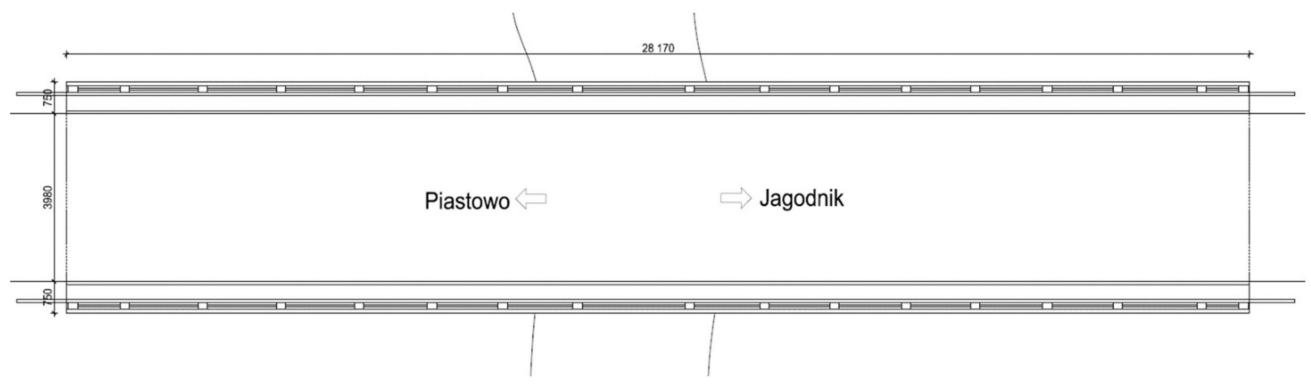

(b)

Figure 1. Jagodnik arch bridge before reconstruction (dimension units-mm): (a) Side view; (b) view from above.

Before the reconstruction process of the 95-year-old concrete arch bridge (see Figure 2) a few fragments of the old concrete were delivered to a laboratory (see Figure 3a) and seven concrete cores were extracted by means of a borehole diamond drill machine (see Figure $3 b)$. After finishing, the length-to-diameter ratio $\mathrm{L} / \mathrm{D}$ was $1(\mathrm{~L}=\mathrm{D}=100 \mathrm{~mm}$; see EN 12504-1 [32] standard), as the thickness of the old structural concrete members was close to $15-16 \mathrm{~cm}$. The cores were marked with the indication of their location and specimen number (location number_specimens number, e.g., 1_2,2_1). Stubs of steel bars 
were tested as well. The concrete fragments E1, E2, and E3 (Figure 3a) were taken from locations indicated in Figure 1a.

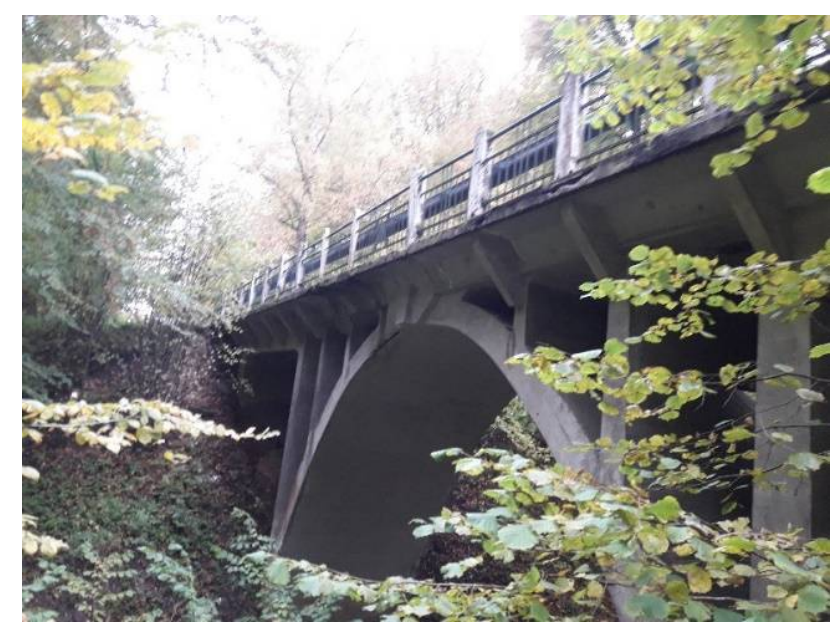

(a)

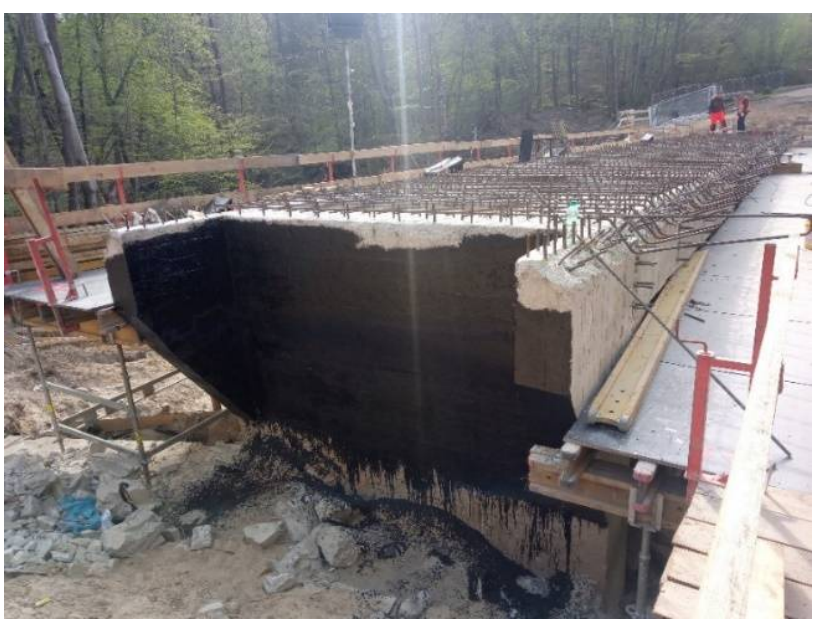

(b)

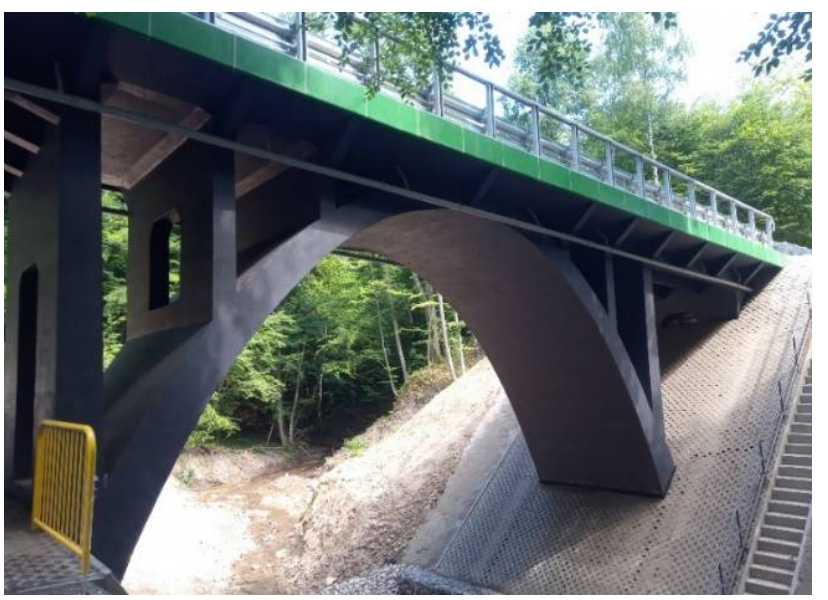

(c)

Figure 2. Jagodnik arch bridge: (a) Before; (b) during; and (c) after reconstruction.

The concrete cylinders were tested in compression to the failure according to EN 123903 standard [33]. Concrete dry density was determined according to method guidelines in EN 12390-7 standard [34], after drying the specimens in a ventilated oven $\left(\mathrm{T}=105 \pm 5^{\circ} \mathrm{C}\right)$ 
until mass stabilization (not more than $0.2 \%$ mass variation with respect to the original mass). The density was derived after cooling down to room temperature in dry conditions. The tests in uniaxial tension of steel reinforcements were performed in accordance with

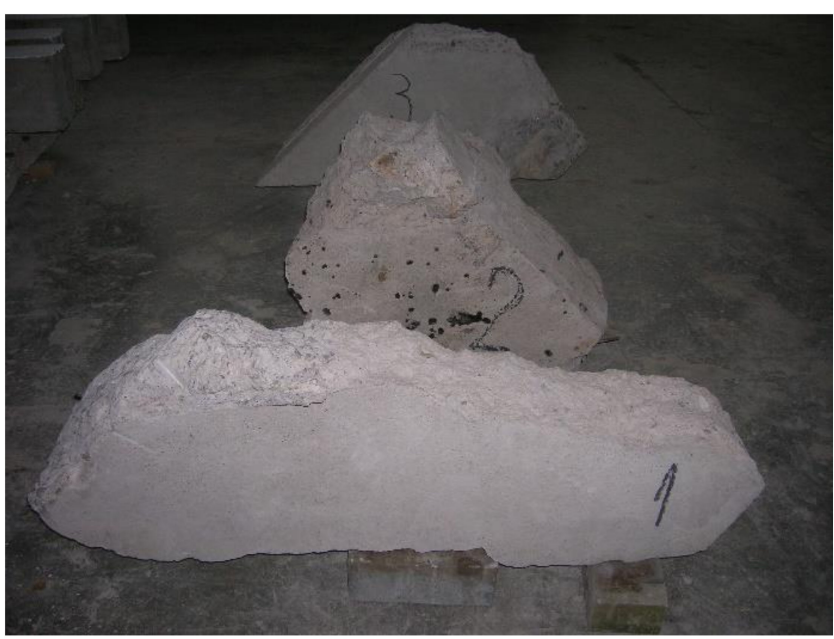

(a)

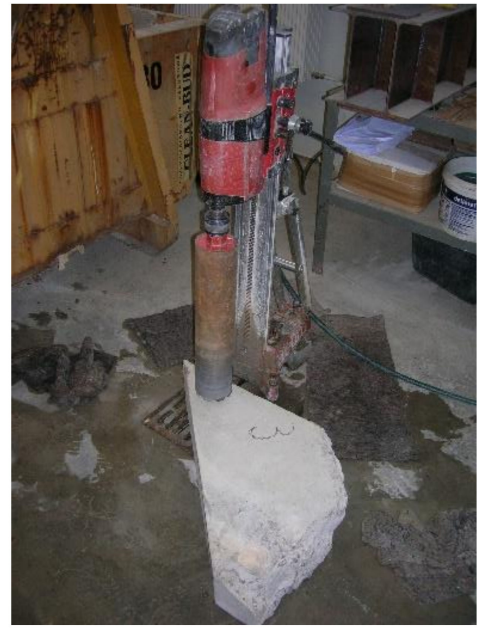

(b)

Figure 3. Preparation of the concrete cores: (a) Fragments of old concrete; (b) drilling process.

\section{Laboratory Test Results and Discussion}

\subsection{Reinforced Steel Tensile Tests}

The reinforcement smooth steel bars of a $6 \pm 0.1 \mathrm{~mm}$ diameter were taken from the old arch bridge and subjected to uniaxial tension by means of the computer-controlled Zwick Z400 testing machine (ZwickRoell GmbH \& Co. KG, Ulm, Germany), see Figure 4. The length of the sample between the grips is $100 \mathrm{~mm}$ and the displacement rate is $5 \mathrm{~mm} / \mathrm{min}$. All tests were performed at room temperature (about $20^{\circ} \mathrm{C}$ ) and were carried out up to specimen failure. Three specimens were chosen for uniaxial tensile tests. During tensile tests, the results were recorded sampling every $10 \mu \mathrm{m}$ (traverse displacement interval), $20 \mathrm{~ms}$ (time interval) and $1 \mathrm{~N}$ (force interval). The tests in tension on the bar stubs were carried out in accordance with ISO 6892-1 standard [35]. The engineering strain at rupture show range from $15 \%$ to near $25 \%$, while the ultimate tensile strength covers the 374-380 MPa interval. The investigated steel rebars are characterized by clear yield strength, strain hardening, and necking range at the stress-strain curves, see Figure 5a. The yield strength was determined in laboratory tests equals $291 \pm 7 \mathrm{MPa}$. The yield strength is defined as the lowest value of stress during plastic yielding, ignoring any initial transient effects. The stress is obtained by dividing the force by the original cross-sectional area of the steel bars.

The Regulations on the Construction and Maintenance of Road Bridges [36] approved by the Polish Minister of Public Works (the ordinance of 9.XI.1925 no. XIII-1386) state the yield strength of steel rebars not to be less than $294 \mathrm{MPa}\left(3000 \mathrm{~kg} / \mathrm{cm}^{2}\right)$. The yield strength (291 $\pm 7 \mathrm{MPa}$ ) specified in laboratory tests corresponds to the guidelines issued in the arch bridge construction time. The Post-Second World War standard PN-B-195 [37] made it possible to apply three types of steel bars of variable yield strengths equals: $196 \mathrm{MPa}$ $\left(2000 \mathrm{~kg} / \mathrm{cm}^{2}\right), 235 \mathrm{MPa}\left(2400 \mathrm{~kg} / \mathrm{cm}^{2}\right)$, and $353 \mathrm{MPa}\left(3600 \mathrm{~kg} / \mathrm{cm}^{2}\right)$. The 5500 steel grade of $500 \mathrm{MPa}$ characteristic yield strength is an abundant concrete reinforcement on bridge and building sites today.

Additionally, two bar stubs were tested at a displacement rate equal to $10 \mathrm{~mm} / \mathrm{min}$ (Figure 5b). The elastic-viscous behavior of the material is evident (the higher the strain rate, the higher the strength at yielding [38]). In Figure 5b, the initial S-shaped loading branch was probably due to grip sliding, while the subsequent mostly-linear branch (stress 
comprised between 150 and $350 \mathrm{MPa}$ ) is related to concrete linear-elastic behavior. Finally, nonlinearity starts at $350 \mathrm{MPa}$.

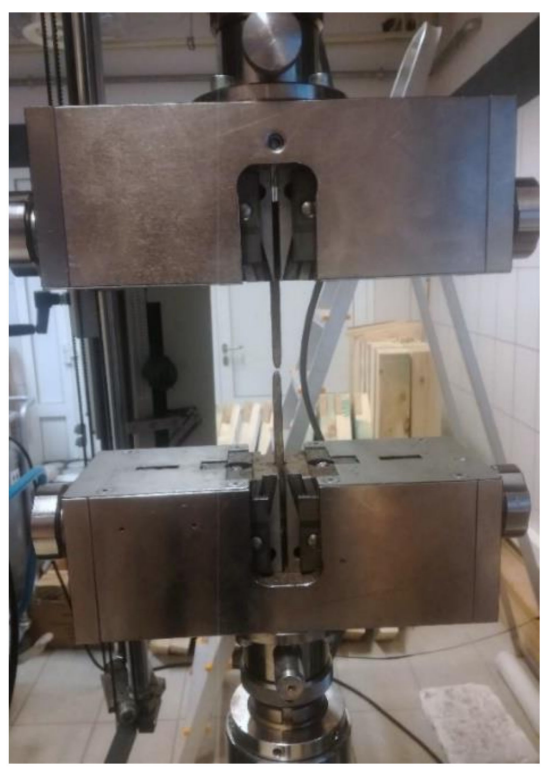

(a)

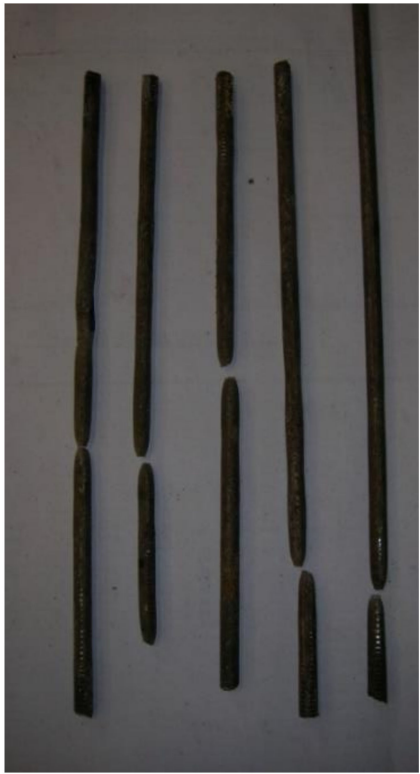

(b)

Figure 4. Uniaxial tensile tests: (a) Test setup; (b) steel bars after failure.

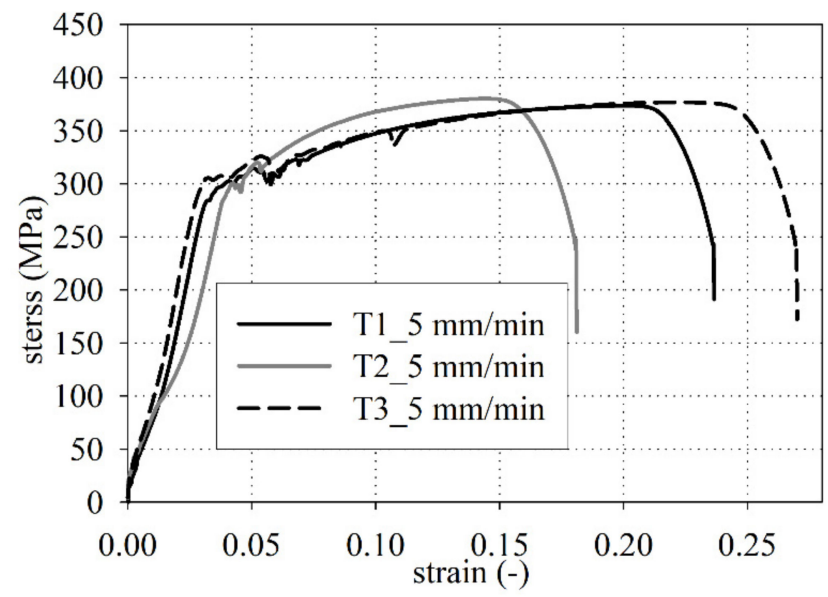

(a)

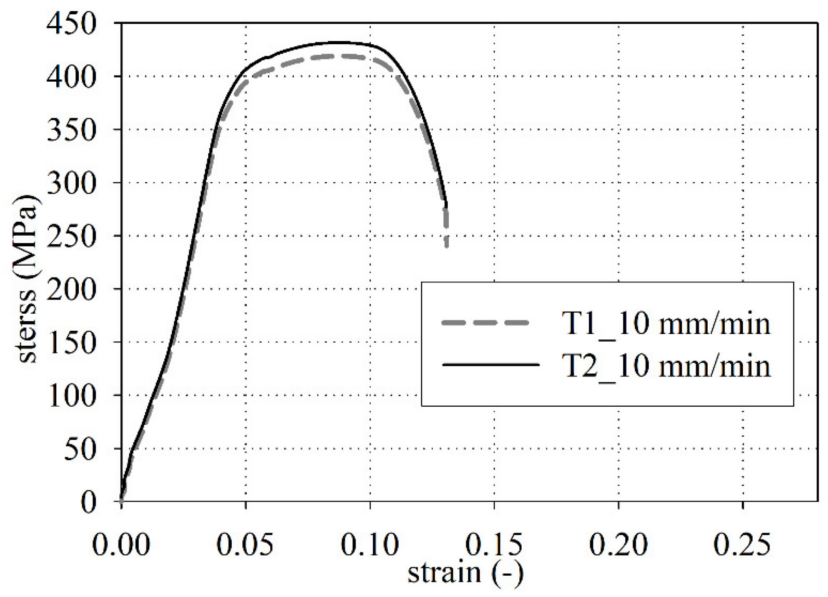

(b)

Figure 5. Stress-strain curves in tension: Test repeatability for two different displacement rates, $5 \mathrm{~mm} / \mathrm{s}(\mathbf{a})$ and $10 \mathrm{~mm} / \mathrm{s}(\mathbf{b})$.

\subsection{Uniaxial Compressive Tests and Dry Density}

The uniaxial compressive experimental tests were conducted on the Advantest 9 C300 KN mechanical testing machine. The experiments were performed to the failure of the concrete cylinder specimens and were used at a constant rate of loading with a range of $0.6 \mathrm{MPa} / \mathrm{s}$ according to EN 12390-3 [33]. The uniaxial compression test results of compressive strength for cylindrical samples are presented in Table 1 . These results are accompanied by the results of the previous investigation. The mean compressive strength of cylindrical samples is equal to $20.5 \pm 1 \mathrm{MPa}$ while the median is equal to $19.7 \mathrm{MPa}$. The strengths of normal-weight concrete determined on cored specimens with a diameter of $100 \mathrm{~mm}$ have no different from those for standardized cube specimens with a $150 \mathrm{~mm}$ side length [39] as opposed to lightweight aggregate concrete [40]. It is worth noting that concrete tends to 
behave as a homogeneous material as long as the sample size is a multiple of the maximum aggregate size, which implies for the diameter of concrete cores to be at least three times larger than the maximum aggregate size. The strength results determined for the concrete cores $f_{\text {ck,is,cycl } 100}$ according to standard EN 12504-1 [32] are identical to the cube strength of $15 \times 15 \times 15 \mathrm{~cm}$ concrete specimens, thus $f_{\text {ck,is,cube }}=f_{\text {ck,is, cycl 100 }}=20.5 \pm 1 \mathrm{MPa}$. The mean compressive strength of old concrete cylindrical samples slightly exceeds the value presented by Ambroziak et al. [30] $(18.8 \pm 0.7 \mathrm{MPa})$ in early investigations.

Table 1. Concrete compressive strength and dry density.

\begin{tabular}{ccc}
\hline Specimens No. & $\begin{array}{c}\text { Compressive Strength } \\
\text { MPa }\end{array}$ & $\begin{array}{c}\text { Dry Density } \\
\text { kg/m } \mathbf{m}^{\mathbf{3}}\end{array}$ \\
& 14.9 & 2166 \\
& 20.0 & 2171 \\
& 19.1 & 2132 \\
Results Obtained by Ambroziak et al. [30] & 18.6 & 2184 \\
& 22.0 & 2155 \\
& 19.9 & 2064 \\
& 19.5 & 2180 \\
& 16.1 & 2174 \\
1_1 & 18.9 & 2147 \\
1_2 & 24.3 & 2157 \\
1_3 & 21.6 & 2186 \\
2_1 & 24.5 & 2207 \\
2_2 & 17.1 & 2173 \\
3_1 & 25.3 & 2170 \\
3_2 & 29.7 & 2193 \\
mean & 17.0 & 2179 \\
median & $20.5 \pm 1$ & $2165 \pm 8$ \\
\hline
\end{tabular}

The concrete had large variations in compressive strength ranging from $14.9 \mathrm{MPa}$ to 29.7 MPa, see Table 1. To properly perform the structural analysis of old concrete structures, it is necessary to evaluate the old concrete compressive strength. The characteristic in-situ compressive cube strength $f_{\mathrm{ck}, \mathrm{is}, \text { cube }}$ according to EN 13791 [41] standard can be determined as:

$$
f_{\mathrm{ck}, \text { is }, \text { cube }}=\min \left\{\begin{array}{c}
f_{\mathrm{m}(\mathrm{n}) \text {,is }}-k_{n} \cdot s \\
f_{\mathrm{is}, \text { lowest }}+M
\end{array}\right\}=\min \left\{\begin{array}{c}
20.5-1.81 \cdot 1 \\
14.9+2
\end{array}\right\}=16.9 \mathrm{MPa}
$$

where $f_{\mathrm{m}(\mathrm{n}) \text {,is }}$ is the mean in-situ compressive strength of $n=16$ test results, $f_{\text {is,lowest }}$ is the lowest in-situ compressive strength test results, $k_{\mathrm{n}}$ is the factor depends on the number of tests results $\left(k_{\mathrm{n}}=1.81\right.$ for tests results equal to 16 , see EN 13791 [41], $s=1 \mathrm{MPa}$ is the standard deviation of in situ compressive strength, $M=2 \mathrm{MPa}$ is the value of margin depend on value of $f_{\text {is,lowest }}$ (see EN 13791 [41], $12 \mathrm{MPa} \geq f_{\text {is,lowest }}<16 \mathrm{MPa}$ ). Ambroziak et al. [30] in their earlier research for old concrete set the same value of the characteristic in-situ compressive cube strength equal to $16.9 \mathrm{MPa}$. The decisive condition for determining the characteristic in-situ compressive cube strength is governed by the value of the lowest in-situ compressive strength. The differences in single cylindrical compressive strength exhibit a non-homogenous distribution of concrete strength in the old concrete arch bridge.

High compressive strength variation among individual concrete specimens is produced by impurities that were identified after uniaxial compressive tests, see Figure $6 \mathrm{a}-\mathrm{f}$. Parts of timber, piece of clay, coarse aggregates (large stones) with cavities and pores were detected in some concrete cores. The maximum aggregate size used in the old concrete mix is up to $20 \mathrm{~mm}$. In a single individual case, the maximum aggregate size was up to $50 \mathrm{~mm}$ (see Figure 6e). Additionally, a wide scatter in compressive strength may be affected by the proportion of cement and aggregate (sand to gravel volumetric ratios) for the old concrete 
mix preparation. Concrete strength may also be affected by different climatic conditions in the course of placement [42]. The specimens were crushed or got separated along a slanted surface and columnar vertical cracking through both ends with no well-formed cones was observed. Generally, the failure mode of core specimens (see Figure $6 a, b$ ) was typical and fulfills requirements guidelines in EN 12390-3 [33] standard.

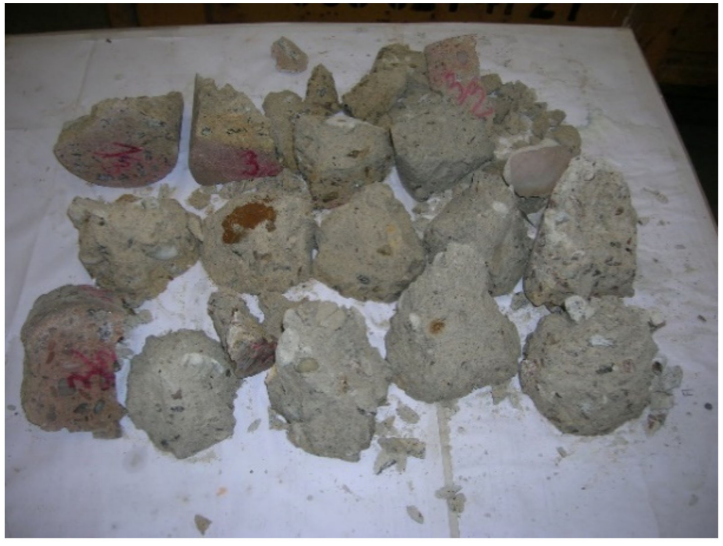

(a)

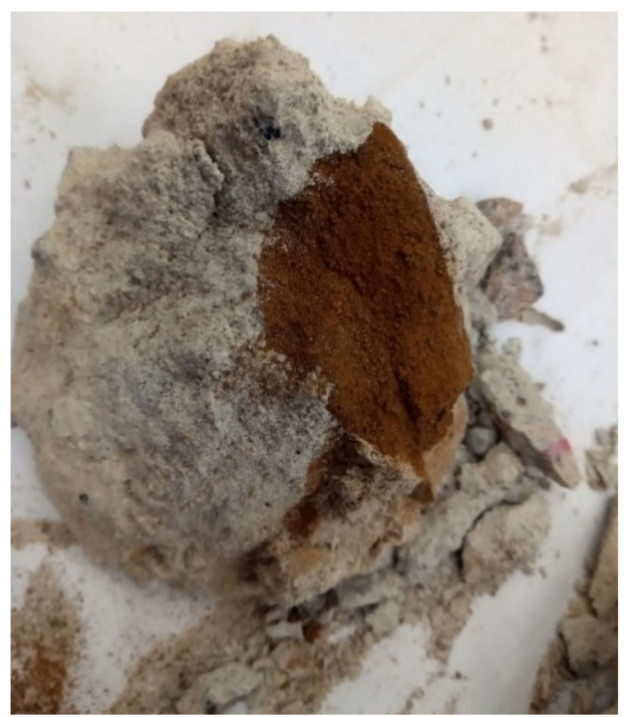

(c)

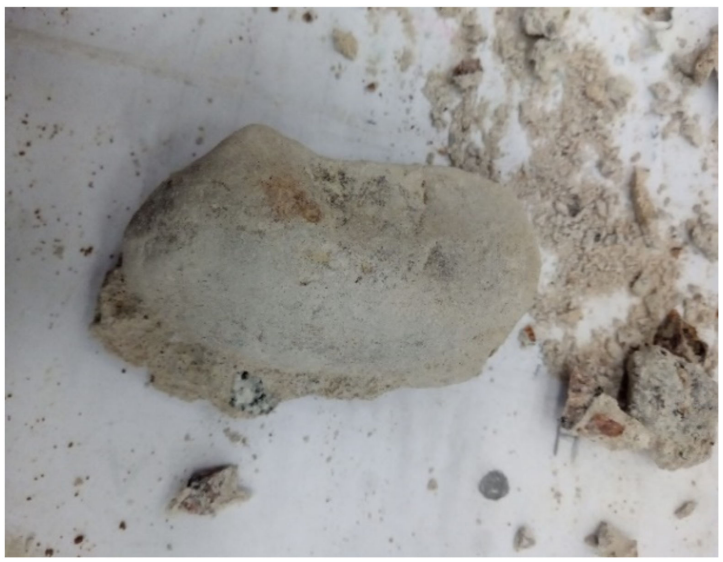

(e)

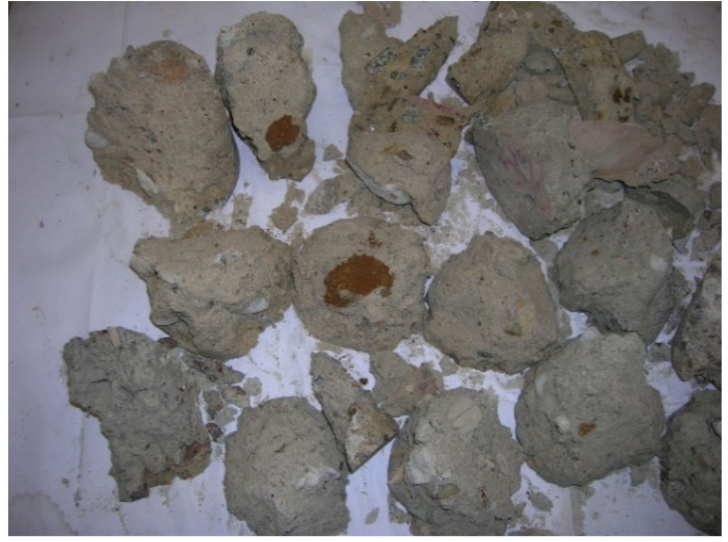

(b)

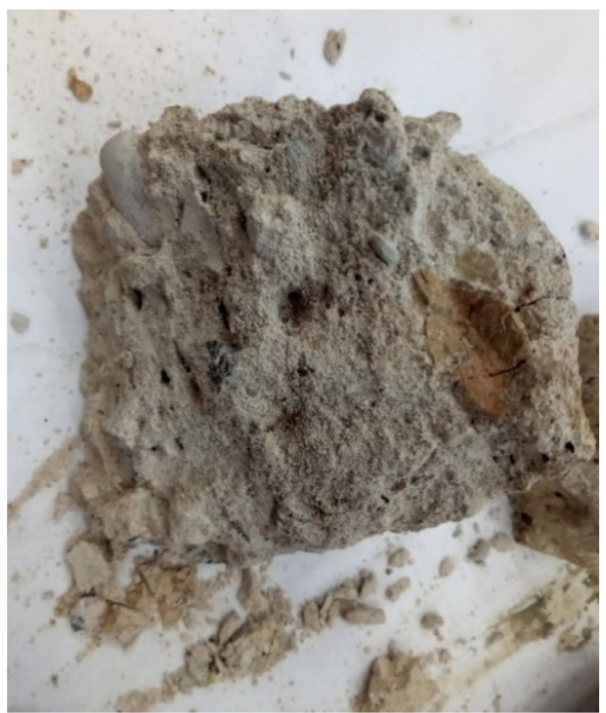

(d)

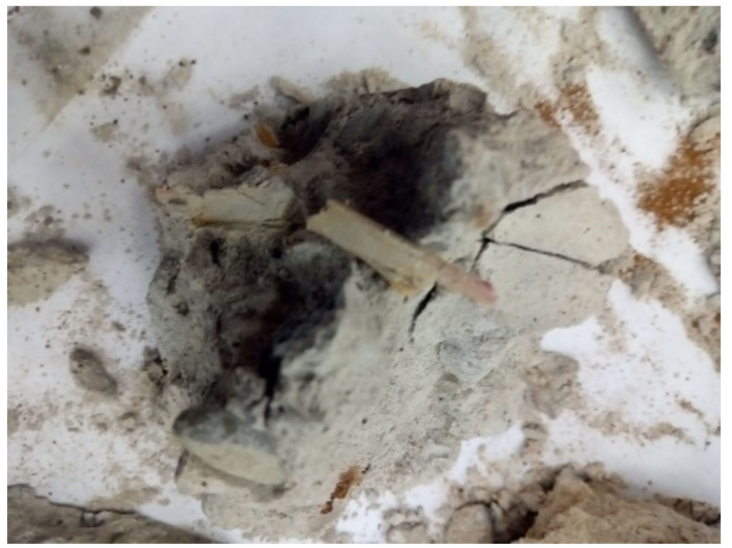

(f)

Figure 6. Concrete specimens after uniaxial compressive tests: (a,b) Form of specimens failure; (c) dirty fine aggregate; (d) clay inclusion; (e) large stone; (f) timber inclusions. 
The reinforced concrete structural guideline [43] issued in January 1916 by the German Committee for Structural Concrete specified two main concrete strength classes $14.7 \mathrm{MPa}$ $\left(150 \mathrm{~kg} / \mathrm{cm}^{2}\right)$ and $17.7 \mathrm{MPa}\left(180 \mathrm{~kg} / \mathrm{cm}^{2}\right)$ for the erection of concrete structures. This guideline has been applicable till September 1925, i.e., while German standard DIN 1045 [44] was introduced. On the other hand, while the 15-18 MPa compressive strength is required the Hennebique recommends a mixture consisting either of a single part cement, two parts sand and four parts gravel or of one part cement, three parts sand and five parts of gravel [45]. The Regulations on the Construction and Maintenance of Road Bridges [36] made it possible to forecast the cube compressive strength of concrete related to the amount of cement to $1 \mathrm{~m}^{3}$ aggregate in concrete mixes, see Table 2. According to these regulations, the amount of water in the concrete mix should be appropriate to locate the mixed concrete in the formwork, or to hand-knead the compacted concrete ball. In the hand-mixing case the amount of cement should be increased by $5 \%$, while consistency of a liquid mix is regarded, the $10 \%$ increment is anticipated.

Table 2. Concrete strength depending on the amount of cement in $1 \mathrm{~m}^{3}$ aggregate (according to guidelines given in [36]).

\begin{tabular}{cc}
\hline $\begin{array}{c}\text { The Amount of Cement } \mathbf{( k g )} \text { in } \mathbf{1} \mathbf{~ m}^{\mathbf{3}} \\
\text { of Aggregate }\end{array}$ & $\begin{array}{c}\text { Forecast Compressive Strength } \\
\mathbf{M P a}\left(\mathbf{k g} / \mathbf{c m}^{\mathbf{2}}\right)\end{array}$ \\
\hline 500 & $19.6(200)$ \\
400 & $16.7(170)$ \\
300 & $13.7(140)$ \\
200 & $9.8(100)$ \\
100 & $5.9(60)$ \\
\hline
\end{tabular}

The Polish standard PN-B-195 [37] specified the forecast compressive strength of concrete with regard to the amount of cement in a $1 \mathrm{~m}^{3}$ concrete mix, the volume ratio of aggregates and the consistency of the ready concrete mix, see Table 3.

Table 3. Concrete strength in $\mathrm{MPa}\left(\mathrm{kg} / \mathrm{cm}^{2}\right)$ depending on the amount of cement in $1 \mathrm{~m}^{3}$ of ready concrete on the degree of liquidity and the volume ratio of aggregate (according to guidelines given in [37]).

\begin{tabular}{ccccc}
\hline Volume Ratios & $\begin{array}{c}\text { The Amount of Cement } \mathbf{( k g )} \\
\text { in } \mathbf{1} \mathbf{~ m}^{\mathbf{3}} \text { of Concrete Mix }\end{array}$ & Liquid Consistency & Plastic Consistency & Rammed Consistency \\
\hline Sand to gravel 1:1 or & 200 & $0(0)$ & $2.9(30)$ & $5.9(60)$ \\
sand to stone & 300 & $4.9(50)$ & $8.8(90)$ & $11.8(120)$ \\
gravel 1:0.8 & 400 & $9.8(100)$ & $13.7(140)$ & $15.7(160)$ \\
\hline Sand to gravel 1:2 or & 200 & $3.9(40)$ & $8.8(90)$ & $11.8(120)$ \\
sand to stone & 300 & $9.8(100)$ & $13.7(140)$ & $15.7(160)$ \\
gravel 1:1.6 & 400 & $13.7(140)$ & $17.7(180)$ & $19.6(200)$ \\
\hline
\end{tabular}

According to the PN-B-195 standard [37] the characteristic strength of concrete, equal $19.6 \mathrm{MPa}\left(200 \mathrm{~kg} / \mathrm{cm}^{2}\right)$ may be achieved by use of $400 \mathrm{~kg}$ of cement with a 1:2 ratio of sand to gravel parts in $1 \mathrm{~m}^{3}$ of finished concrete of a rammed concrete consistency. The standard PN-B-195 [46] in its early version of 1934 specified the strength equal to $16.7 \mathrm{MPa}$ $\left(170 \mathrm{~kg} / \mathrm{cm}^{2}\right)$ with the same amount of cement. The lack of clear and detailed water dosage guidelines produced variable compressive strengths of old concrete structures. The standard PN-B-195 [37] emphasized that the amount of water should be limited in ready concrete mixes of $0 \mathrm{MPa}\left(0 \mathrm{~kg} / \mathrm{cm}^{2}\right.$, see Table 3$)$ concrete strength class when the liquid concrete mix consistency is assumed. The water-to-cement ratio is defined in the present standards and guidelines regarding concrete mixes, specifying the proper amount of water in concrete mix for a prescribed concrete strength class.

The method specified in EN 12390-7 [34] standard is applied for determining the dry density of 95-year-old concrete. The tested specimens were dried in a ventilated oven at 
$105 \pm 5{ }^{\circ} \mathrm{C}$ until the mass relative decrement reaches $0.2 \%$. Before weighing each specimen was cooled to near room temperature in a dry airtight vessel. The mean dry density value is equal to $2164 \pm 9 \mathrm{~kg} / \mathrm{m}^{3}$ while the median is equal to $2173.5 \mathrm{~kg} / \mathrm{m}^{3}$, see Table 1 . According to the EN 206 standard [47] and the ACI 318-19 code [48], the investigated old concrete satisfies the conditions for the normal-weight concrete category.

\subsection{Modulus of Elasticity and Durability}

The secant modulus of elasticity in the range 0 to $40 \%$ of the ultimate strength (according to EN 1992-1-1 [49] standard) is assumed 22,890 MPa (mean value of the modulus of elasticity, see Ambroziak et al. [30]) with regard to structural analysis of old arch concrete bridge. The ASTM C469 M standard [50] guideline was used to determine the modulus of elasticity. Diamond-drilled concrete cores with a length to diameter ratio of 1.50 were used in a compressometer device to measure the static modulus of elasticity. The regulations [36], applicable in time of the bridge erection indicated that the concrete compressive strength greater or equal to $13.73 \mathrm{MPa}$ corresponds to the modulus of elasticity $14,715 \mathrm{MPa}$ $\left(150,000 \mathrm{~kg} / \mathrm{cm}^{2}\right)$. The modulus of elasticity assumed for investigated old concrete is 1.55 times greater than the value specified in regulations [36], possibly due to various aggregates types in concrete mixes.

Based on the early experimental investigation performed by Ambroziak et al. [30] it can be concluded that the 95-year-old concrete has good freezing resistance. The chloride content of the old concrete did not exceed $0.2 \%$ by mass of cement; thus, the old concrete arch bridge was not exposed to chloride attack. The $\mathrm{pH}$ values for the old concrete indicated that there is no corrosion of the steel rebar's. Nevertheless, the old concrete has large variations in depth of the carbonated zone ranging from 20 to $55 \mathrm{~mm}$. Despite the large depth of the carbonated zone, the $\mathrm{pH}$ of the old concrete is still in the safety range.

\section{Structural Analysis}

\subsection{Description of FEM Model}

The three-dimensional finite element model of the 95-year-old concrete arch bridge is built (see Figure 7), followed by numerical calculations and structural analysis. The SOFiSTiK structural engineering system is applied in numerical calculations. This software is frequently used in the design and analysis of bridge structures [51-55]. In the present structural analysis, the traffic loads class $\mathrm{C}$ are assumed, according to standard PN-S10030 [56]. This standard was applicable in Poland during the reconstruction design process of the old bridge. The traffic load is composed of $\mathrm{q}$ and $\mathrm{K}$ types of loads, see Figure 8 . The load values of $\mathrm{q}$ and $\mathrm{K}$ type are equal to $2 \mathrm{kPa}$ and $400 \mathrm{kN}(8 . \mathrm{P}=8.50 \mathrm{kN}=400 \mathrm{kN})$, respectively. The distribution of q load (arbitrary distribution) and location of $\mathrm{K}$ load have to produce the largest responses in analyzed structural elements. Besides this traffic load, permanent loads are also imposed (dead-weight and bridge equipment's loads). The shell (SH3 D) and 3 D beam (B3 D) finite elements (FE) are applied in the FEM model of the arch bridge. The finite elements adopted in this study are 4-node isoparametric shell finite elements of DKMQ type and 2-node $3 \mathrm{D}$ beam elements of the Timoszenko type, C0 class with linear shape functions. The mesh independence study of the bridge finite element model is carried out to ensure that the results of an analysis are not affected by changing the size of the mesh. The FEM model of the old concrete arch bridge is meshed by 45,075 shell elements (modeled slab and concrete arch) and $7763 \mathrm{D}$ beam elements (girders), the model includes 42,223 nodes with and 940 support constraints (Figure 7). It should be noted, that the authors' experiences in the design and monitoring of bridge structures are also exploited during the construction of the FEM model $[57,58]$. It can be pointed, that more detailed numerical models are created to investigate the individual structural elements of bridges and comparisons them with laboratory tests $[59,60]$. 


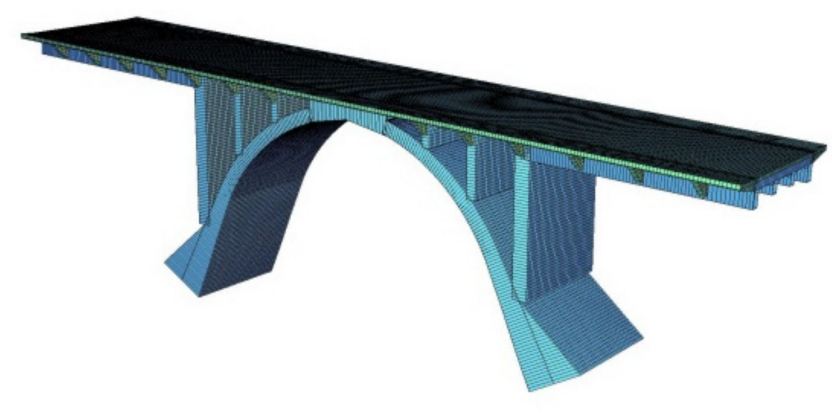

(a)

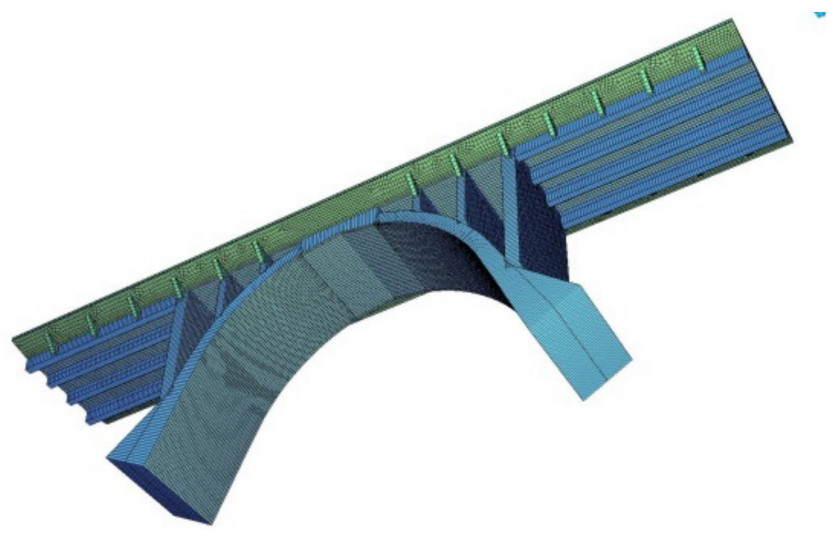

(b)

Figure 7. FEM model: (a,b) 3 D views.

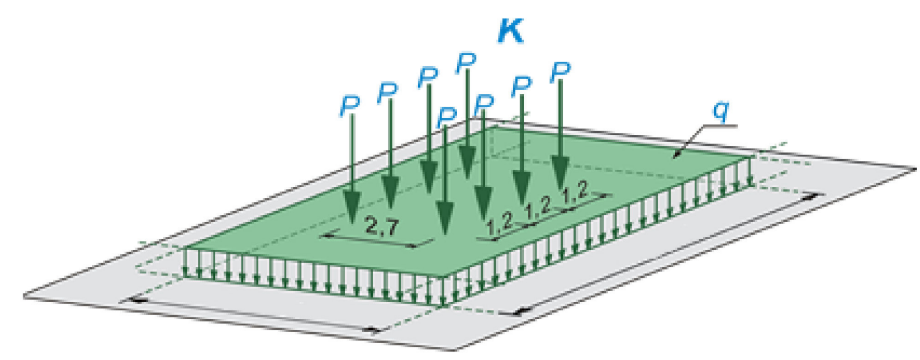

Figure 8. Traffic loads class C (q and K types) according to standard PN-S-10030 [56].

\subsection{Results of Structural Analysis}

The numerical analysis allows to evaluate the internal forces acting on the sections and specifically their largest values, which in turns make it possible to define the geometry of the members and later to proceed with the verifications at the Serviceability Limit State (SLS) under the service loads, and at the Ultimate Limit State (ULS) under the ultimate loads. The maps of bending moments in the deck slab and the concrete arch under the dead weight of the structure and loads of the bridge equipment are determined in Figures A1 and A2 respectively. On the other hand, for the moving loads $q$ and $K$ of class $C$ (see Figure 8), the envelope maps of characteristic values of bending moments in the deck slab (see Figure A3) and the envelope maps of characteristic values of forces in the concrete arch (see Figure A4) are presented. In Figures A5 and A6 the characteristic values of bending moments for inner and outer girders are shown. The largest bending moments and axial forces at the chosen, critical cross-sections of a superstructure correspond to the most unfavorable combinations of permanent and live loads according to PN-S-10030 [56], these values are presented in Table 4 . The lack of symmetry in the results of internal forces between the right and left span girders results from different spans (see Figure 1). The results for the outer girder and the inner girder are similar in the longer span (right span, see Table 4) where they have a similar height, while in the shorter span (left span) the results differ significantly between the outer girder and inner girder because the girders have different constructional heights.

The site inspection and inventory of old arch bridge make it possible to assess the amount of reinforcement in structural elements, see Table 5. Concrete detector for rebar localization, depth measurement, and size estimation are necessary for the proper estimation of steel reinforcements in the existing old concrete bridge. New technologies, methods, and systems are still developed for the detection of steel rebars in concrete structures [61-64]. 
Table 4. Characteristic and design value of internal forces under designed loads.

\begin{tabular}{|c|c|c|c|c|c|c|c|}
\hline \multirow{3}{*}{ Loads } & \multicolumn{2}{|c|}{ Right Span } & \multicolumn{2}{|c|}{ Left Span } & \multicolumn{3}{|c|}{ Slab and Arch } \\
\hline & \multirow{2}{*}{$\begin{array}{c}\text { Outer } \\
\text { Girder } \\
M \text { kNm }\end{array}$} & \multirow{2}{*}{$\begin{array}{c}\text { Inner } \\
\text { Girder } \\
M \mathrm{kNm}\end{array}$} & \multirow{2}{*}{$\begin{array}{c}\text { Outer } \\
\text { Girder } \\
M \mathrm{kNm}\end{array}$} & \multirow{2}{*}{$\begin{array}{c}\text { Inner } \\
\text { Girder } \\
M \mathrm{kNm}\end{array}$} & \multirow{2}{*}{$\begin{array}{c}\text { Center } \\
\text { Deck Plate } \\
M \text { kNm }\end{array}$} & \multicolumn{2}{|c|}{ Arch } \\
\hline & & & & & & $M \mathrm{kNm}$ & $N \mathbf{k N}$ \\
\hline L1-characteristic load by dead-weight & 9.8 & 10.0 & 8.4 & 3.7 & 1.4 & 56.3 & 560.4 \\
\hline L2-characteristic load by bridge equipment's & 5.1 & 6.1 & 4.5 & 2.5 & 0.9 & 16.2 & 115.0 \\
\hline L3-characteristic live load, standard load q type & 1.5 & 1.9 & 1.4 & 0.8 & 0.5 & 6.8 & 37.4 \\
\hline $\begin{array}{l}\text { L4-characteristic live load, standard load K } \\
\text { typewithout the dynamic factor } \phi\end{array}$ & 17.0 & 15.3 & 16.0 & 6.5 & 9.2 & 38.7 & 196.8 \\
\hline Sum: $\mathrm{L} 1 \div \mathrm{L} 4$ & 33.4 & 33.3 & 30.3 & 13.5 & 12 & 118 & 909.6 \\
\hline dynamic factor $\phi$ & \multicolumn{2}{|c|}{1.318} & \multicolumn{2}{|c|}{1.324} & 1.325 & \multicolumn{2}{|c|}{1.284} \\
\hline design value with dynamic factor $\phi$ & 55.1 & 53.8 & 50.4 & 22.3 & 21.7 & 172.6 & 1280.3 \\
\hline
\end{tabular}

Table 5. Materials characteristic and calculated extreme stresses in concrete and steel rebar's.

\begin{tabular}{|c|c|c|c|c|c|c|}
\hline \multirow{2}{*}{ Properties } & \multicolumn{2}{|c|}{ Left Span } & \multicolumn{2}{|c|}{ Right Span } & \multicolumn{2}{|c|}{ Slab and Arch } \\
\hline & Outer Girder & Inner Girder & Outer Girder & Inner Girder & Deck Plate & Arch \\
\hline Steel rebar's (bottom) & & & $6 \#$ & & $14 \# 12 / \mathrm{m}$ & $5 \# 12 / \mathrm{m}$ \\
\hline Design yield strength of reinforcement & \multicolumn{6}{|c|}{$f_{\mathrm{yk}}=291 \mathrm{MPa}$, thus $f_{\mathrm{yd}}=\frac{f_{\mathrm{yk}}}{\gamma_{\mathrm{s}}}=\frac{291}{1.15}=257 \mathrm{MPa}$} \\
\hline Design compressive strength of concrete & \multicolumn{6}{|c|}{$f_{\mathrm{ck}, \mathrm{is}, \mathrm{cube}}=16.9 \mathrm{MPa}$, thus $f_{\mathrm{cd}}=\alpha_{\mathrm{cc}} \frac{f_{\mathrm{ck}}}{\gamma_{\mathrm{c}}}=1.0 \frac{0.8 \cdot 16.9}{1.4}=9.7 \mathrm{MPa}$} \\
\hline $\begin{array}{c}\text { Determined largest stress in steel } \\
\text { rebar's, } \mathrm{MPa}\end{array}$ & 32.7 & 31.9 & 38.1 & $16.8^{\gamma_{c}}$ & 78.6 & 145.6 \\
\hline $\begin{array}{c}\text { Determined highest stress in } \\
\text { concrete, } \mathrm{MPa}\end{array}$ & 2.2 & 2.2 & 3.0 & 1.3 & 3.3 & 9.3 \\
\hline
\end{tabular}

The design yield strength of reinforcement $\left(f_{\mathrm{yd}}\right)$ and design compressive strength of old concrete $\left(f_{\mathrm{cd}}\right)$ are determined according to specified characteristic yield strength of reinforcement $\left(f_{\mathrm{yk}}\right)$, characteristic compressive strength of concrete $\left(f_{\mathrm{ck}}\right)$, partial safety factors for reinforcement $\left(\gamma_{s}\right)$ and concrete $\left(\gamma_{c}\right)$ material properties. The partial safety factors $\gamma_{\mathrm{s}}$ and $\gamma_{\mathrm{c}}$ are assumed according to Table NA.2 guidelines in National Annex to PN-EN 1992-1-1 [65]. The characteristic yield strength of steel rebars and the characteristic compressive strength of concrete are specified in laboratory tests.

The largest stresses in reinforced steel and old concrete in representative structural elements of the arch bridge are determined and collected in Table 5 . The highest stress in steel rebar's equals $145.6 \mathrm{MPa}$, approximately equal to $57 \%$ of the design yield strength of reinforcement, $f_{\mathrm{yd}}=257 \mathrm{MPa}$, see Table 5 . The specified maximal compressive stress in old concrete arch bridge is $9.3 \mathrm{MPa}$, approximately equal to $96 \%$ of the design compressive strength of concrete $f_{\mathrm{cd}}=9.7 \mathrm{MPa}$.

The largest displacement under the SLS combination of the traffic loadings (see Figure A7) is equal to about $1.3 \mathrm{~mm}$. According to the assumptions of PN-S-10042 [66] standard, the permissible deflection of reinforced concrete beam elements in continuous systems (in this case the largest spans of the analysed bridge, see Figures 1a and A7) is $f_{\text {perm }}=L / 1000=(6380+2 \cdot 250) / 1000=6.88 \mathrm{~mm}$. Determined largest deflections fulfils the SLS condition $f_{\max }=1.32 \mathrm{~mm}<f_{\text {perm }}=6.88 \mathrm{~mm}$.

Structural analysis indicated that the 95-year old concrete arch bridge structure satisfies SLS and ULS requirements under the traffic loads class C according to PN-S-10030 [56] standard. Sometimes the car traffic on old bridges is not permitted and after reconstructions are able to meet the requirements for footbridges only [67]. The structural analysis confirmed the validity of the adopted design solutions. On top of the existing old deck structure, a new deck slab with pavement covers is designed and the entire surface of the old concrete is protected with repair mortars. The task of the new deck slab is not only to strengthen the structure but also to increase the resistance to present environmental influences and also the shear capacity of the deck slab. The higher strength class of con- 
crete is designed and used to fulfill the EN 206 [47] standard requirement of the present exposure classes.

All newly erected bridges and old rebuilt bridges need a detailed assessment and dynamic analysis. In this paper, this analysis is not included but the dynamic analysis is performed to properly assess the properties of the 95-year-old arch concrete bridge. It should be noted, that improper design of bridge structure cause the risk of excessive structural vibrations throughout the operation [68-73].

\section{Conclusions}

A 95 year-old concrete arch bridge in Jagodnik (northern Poland) is examined in this paper, from the properties of the materials—by testing samples in a lab-to the structural behavior-by finite-element modeling, with the following results:

- The investigated core samples of the 95-year-old concrete exhibit a high compressive strength scatter from 14.9 MPa to $29.7 \mathrm{MPa}$, see Table 1. These results serve as evidence of the very non-homogenous distribution of concrete strength in the old concrete arch bridge.

- The concrete specimens tested in compression show that there is a large number of impurities in the old concrete (i.e., pieces of timber and clay, coarse aggregates, large stones) with cavities and soft pockets. The scatter in the mechanical properties is, therefore, due to either very low quality-control in the building phase or very poor concrete technology based on portable concrete mixers and hand-made proportioning of concrete constituents.

- The mean dry density of the original concrete equals $2165 \pm 8 \mathrm{~kg} / \mathrm{m}^{3}$, see Table 1 . The old concrete satisfies the conditions for normal-weight concrete category according to the EN 206 standard [47] and the ACI 318-19 code [48].

- The in-situ compressive cube strength $f_{\text {ck,is,cube }}$ equals $16.9 \mathrm{MPa}$, according to EN 13791 [41] standard. Calculated and applied in structural analysis, the design compressive strength of 95-year-old concrete $f_{\text {cd }}$ equals 9.7 MPa.

- The reinforced steel tensile tests confirm that the characteristic yield strength specified in laboratory tests $\left(f_{\mathrm{yk}}=291 \pm 7 \mathrm{MPa}\right)$ corresponds to the guidelines [36] issued in the time of the 95-year-old arch bridge construction.

- The highest stress in steel rebars of structural cross-section is approximately equal to $57 \%$ of the design yield strength of reinforcement, the maximum compressive stress in the original parts of the arch bridge is approximately equal to $96 \%$ of the design compressive strength of concrete.

- The largest displacement under the SLS combination of the traffic loadings satisfies the SLS condition according to o PN-S-10042 [66] standard. The determined largest deflections are five times less than the permissible deflection.

- The structural analysis confirmed the validity of the adopted design solutions. On top of the existing old deck structure, a new deck slab with pavement covers is designed and the entire surface of the old concrete is protected with repair mortars. The task of the new deck slab is not only to strengthen the structure but also to increase the resistance to present environmental influences and also the shear capacity of the deck slab. The higher strength class of concrete is designed and used to fulfill the EN 206 [47] standard requirement of the present exposure classes.

- The 95-year-old arch bridge satisfies bearing capacity (ULS) and SLS conditions, capable of carrying designed traffic loads class C according to PN-S-10030 [56] in extended working life.

This paper provides scientists, engineers, and designers with experimental and structural assessments of the 95-year-old concrete. The study confirms the old arch bridge ability to carry newly designed traffic loads and helped give him a new structural life and extend his working life. Lots of existed old and historic bridge structures require restoration and reconstruction, which require not only a sound financial plan and the expertise of civil engineers, but-more often than not-the expertise of the scientific community, for an 
appropriate assessment of structural safety. Old bridge structures should return like the Phoenix from their ashes and recovery their past appearance. The protection of old bridges coincides with the preservation of their cultural heritage.

Author Contributions: Conceptualization, A.A.; methodology, A.A. and M.M.; validation, A.A. and M.M.; formal analysis, A.A. and M.M.; investigation, A.A. and M.M.; resources, A.A. and M.M.; data curation, A.A. and M.M.; writing-original draft preparation, A.A. and M.M.; writing-review and editing, A.A.; visualization, A.A.; supervision, A.A.; project administration, A.A. All authors have read and agreed to the published version of the manuscript.

Funding: This research received no external funding.

Institutional Review Board Statement: Not applicable.

Informed Consent Statement: Not applicable.

Data Availability Statement: All laboratory test results (data) are included in Table 1 in the present paper.

Conflicts of Interest: The authors declare no conflict of interest.

\section{Appendix A FEM Calculation Results}

The chosen results of internal forces used in the verification and design process (see Table 4) are presented in Figures A1-A6. In Figure A7 extreme displacement under the SLS combination of traffic loadings is given.

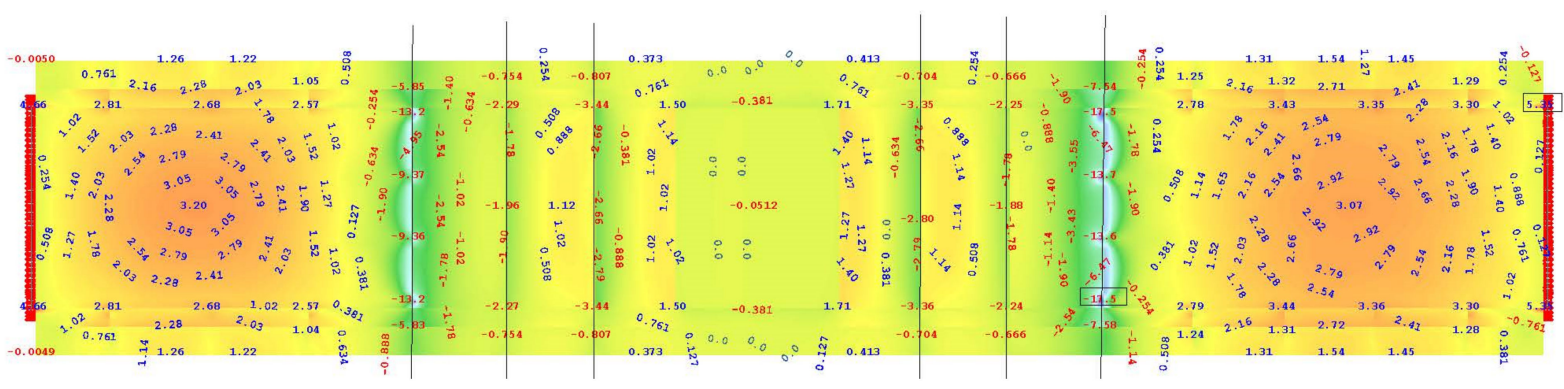

(a)

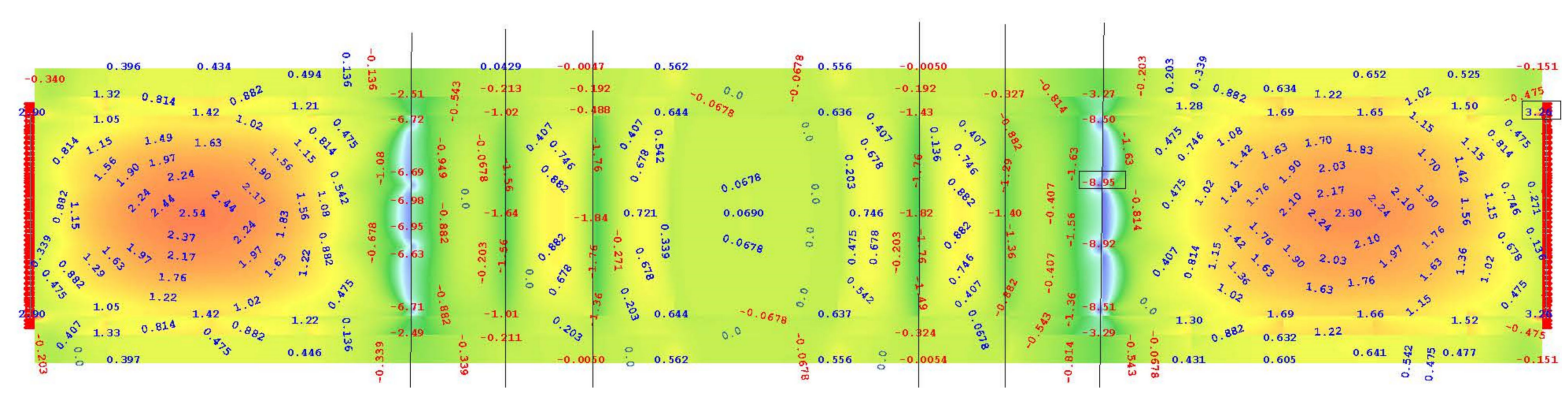

(b)

Figure A1. Maps of characteristic values of bending moments $M x x(k N m)$ in the deck slab: (a) Dead weight; (b) bridge equipment loads. 


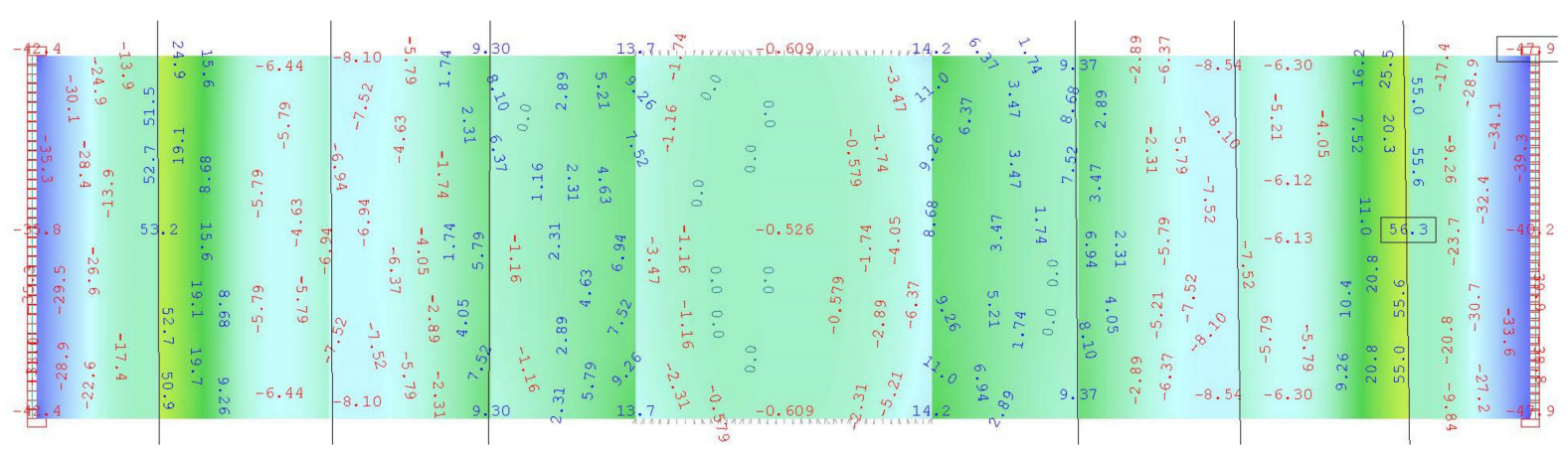

(a)

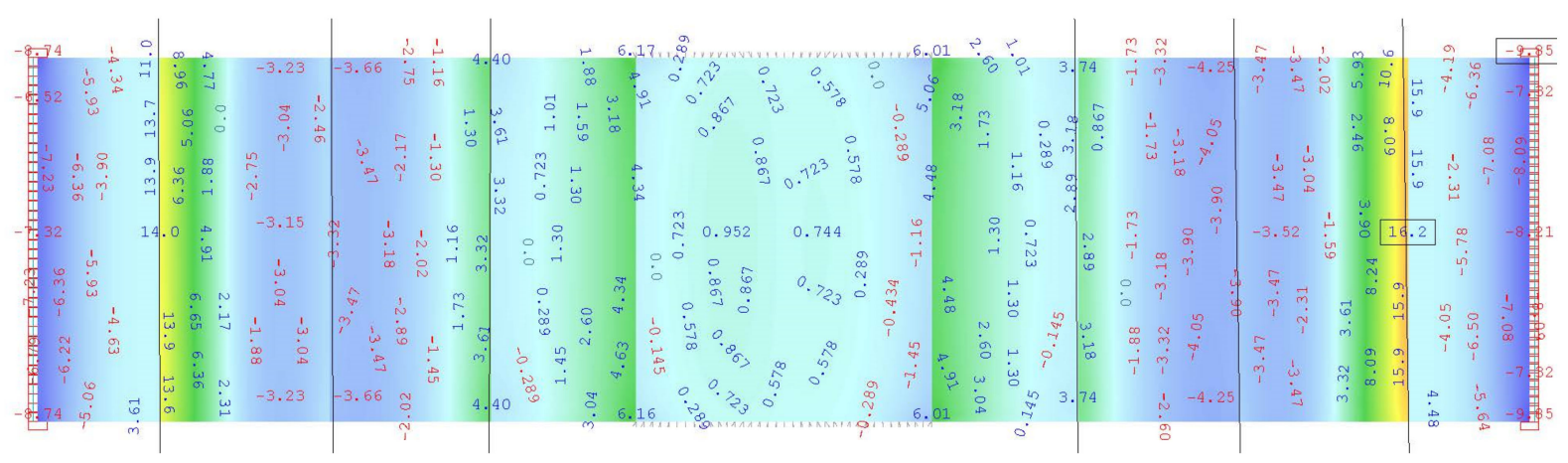

(b)

Figure A2. Maps of characteristic values of bending moments $M x x(k N m)$ in the concrete arch: (a) Dead weight; (b) bridge equipment loads.

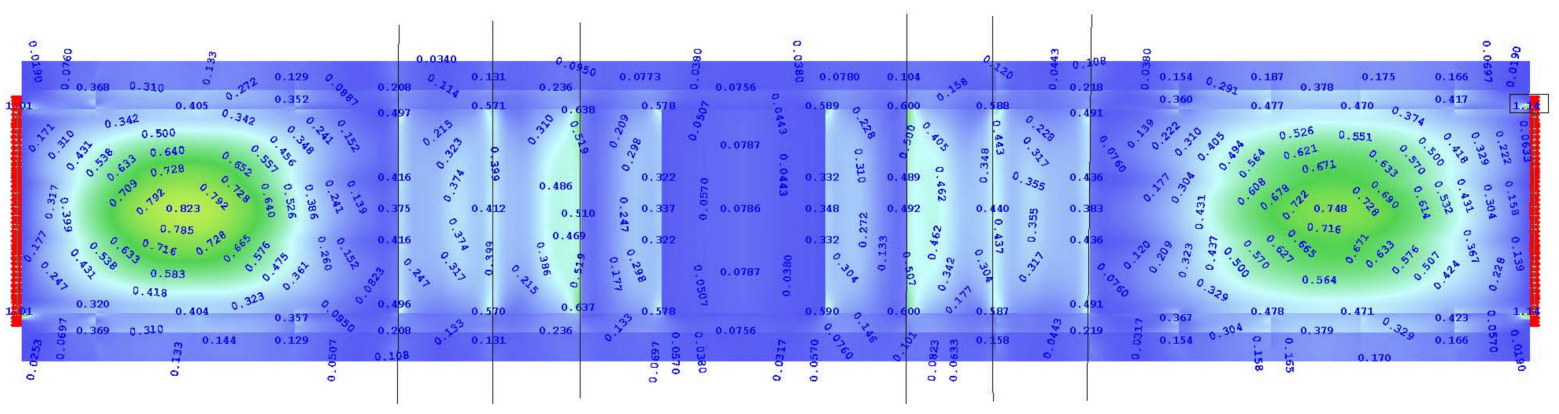

(a)

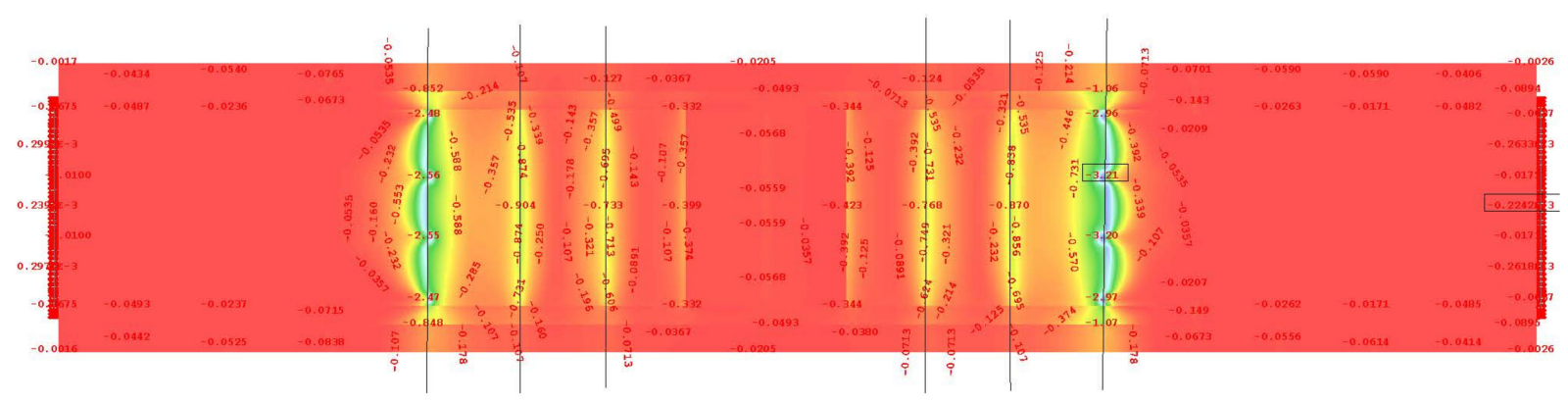

(b)

Figure A3. Cont. 


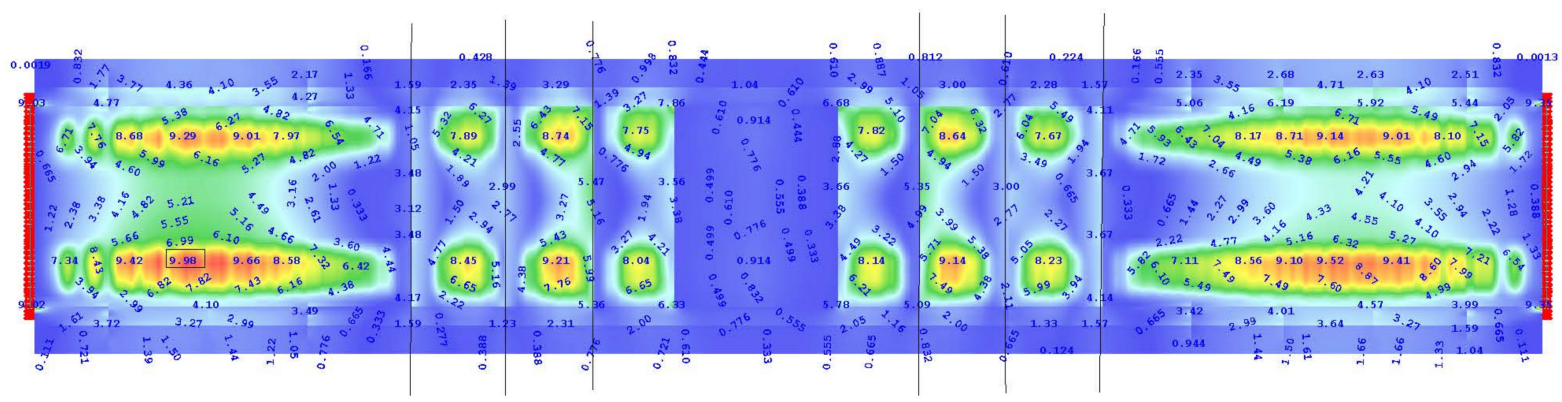

(c)

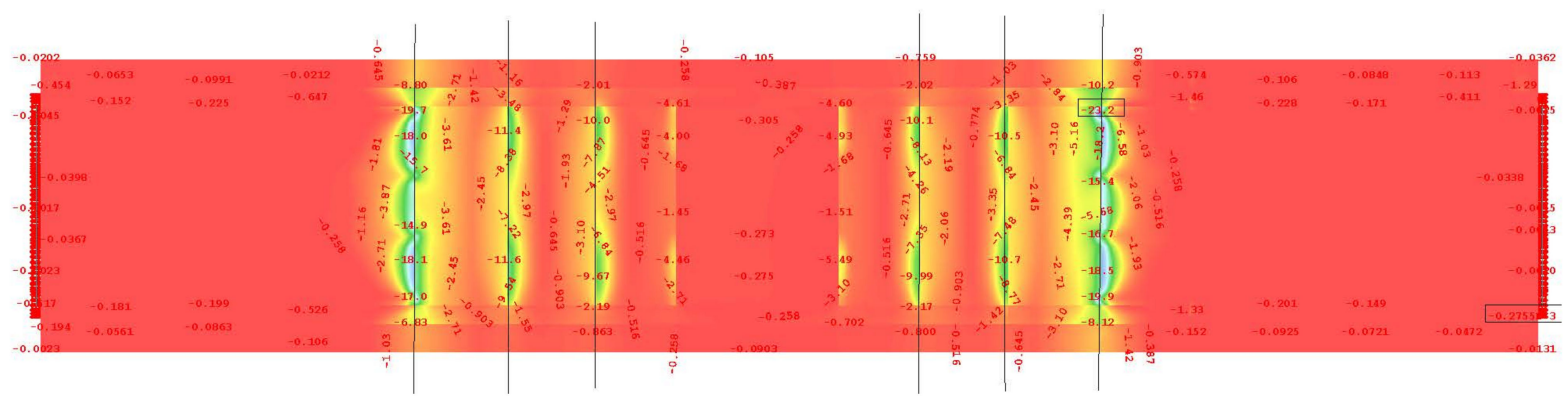

(d)

Figure A3. The envelope maps of characteristic values of bending moments $M x x(k N m)$ in the deck plate: (a) Max Mxx $(\mathrm{kNm})$ under the moving load q of class $\mathrm{C}$; (b) $\min \mathrm{Mxx}(\mathrm{kNm})$ under the moving load q of class $\mathrm{C}$; (c) max Mxx (kNm) under the moving load $\mathrm{K}$ of class $\mathrm{C}$; (d) $\min \mathrm{Mxx}(\mathrm{kNm})$ under the moving load $\mathrm{K}$ of class $\mathrm{C}$.

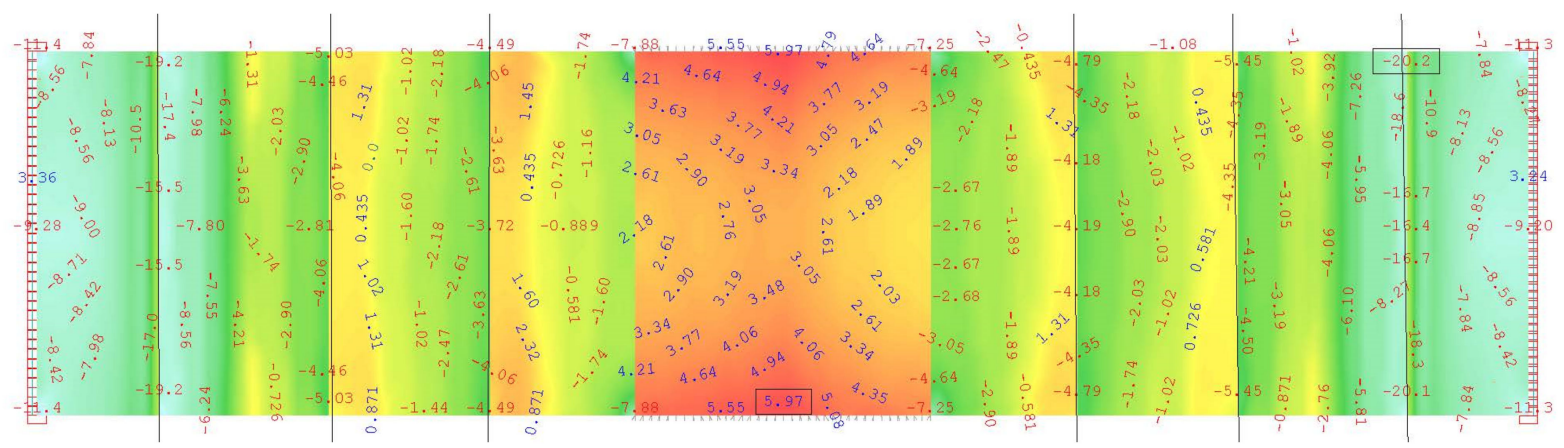

(a)

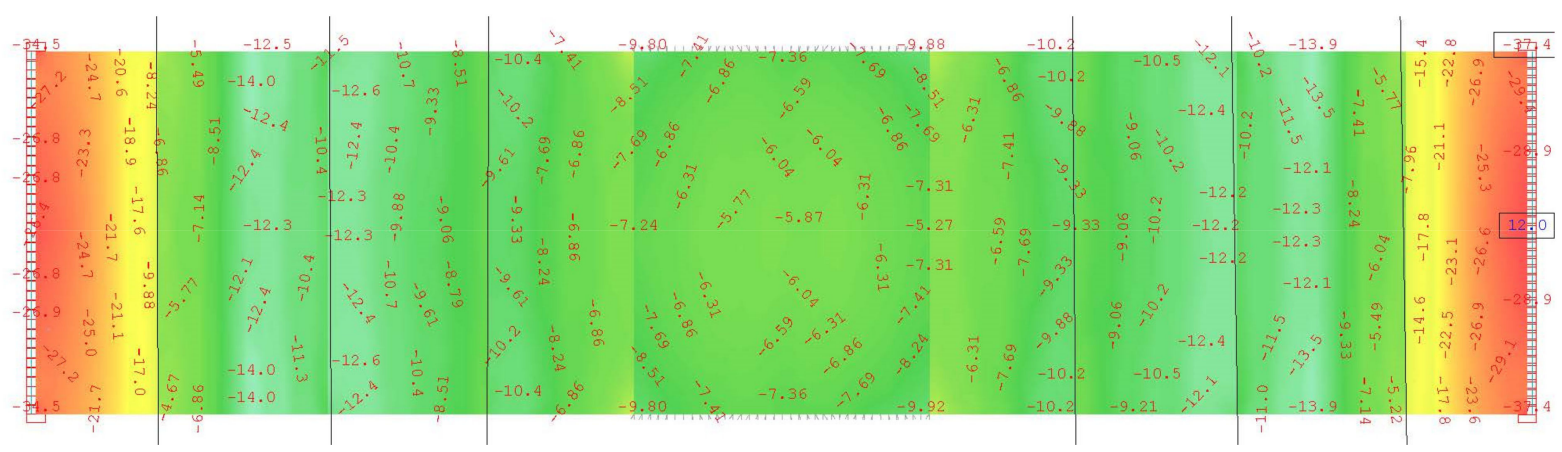

(b)

Figure A4. Cont. 


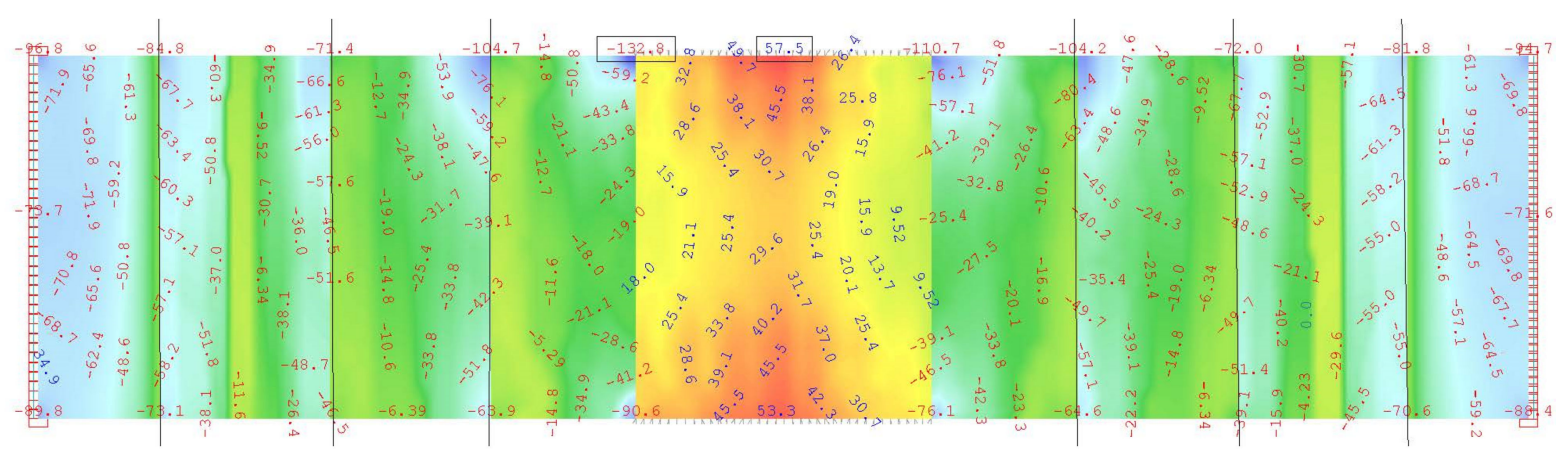

(c)

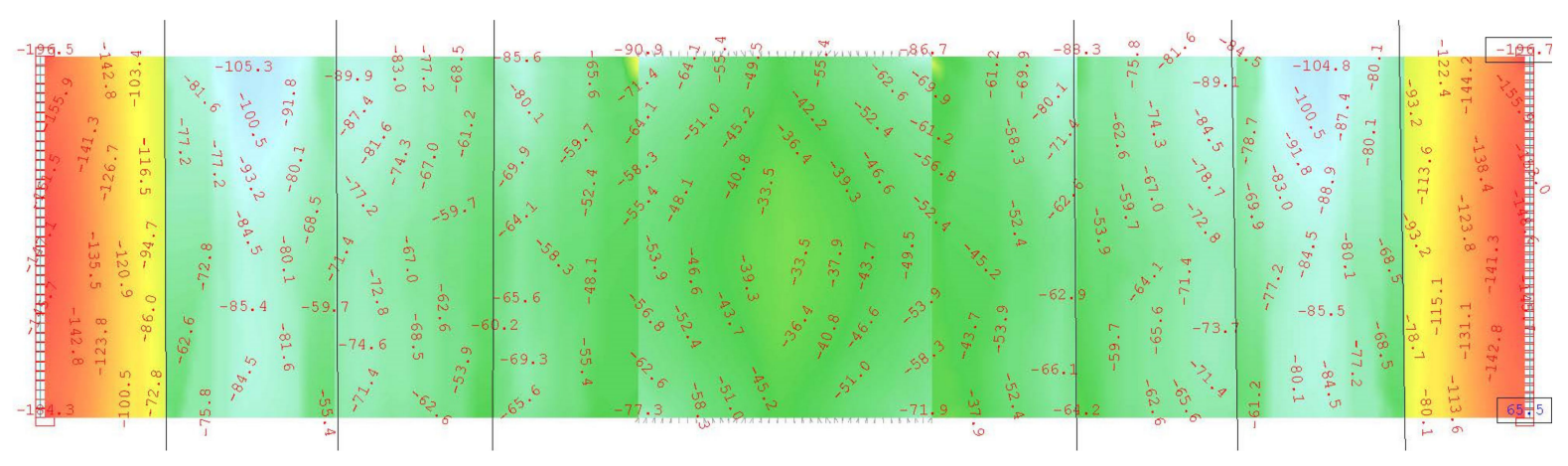

(d)

Figure A4. Envelope maps of characteristic values of forces $N x x(k N)$ in the concrete arch: (a) Max Nxx (kN) under the moving load q of class $\mathrm{C}$; (b) min $\mathrm{Nxx}(\mathrm{kN})$ under the moving load q of class $\mathrm{C}$; (c) max Nxx (kN) under the moving load $\mathrm{K}$ of class C; (d) min Nxx (kN) under the moving load K of class $C$.

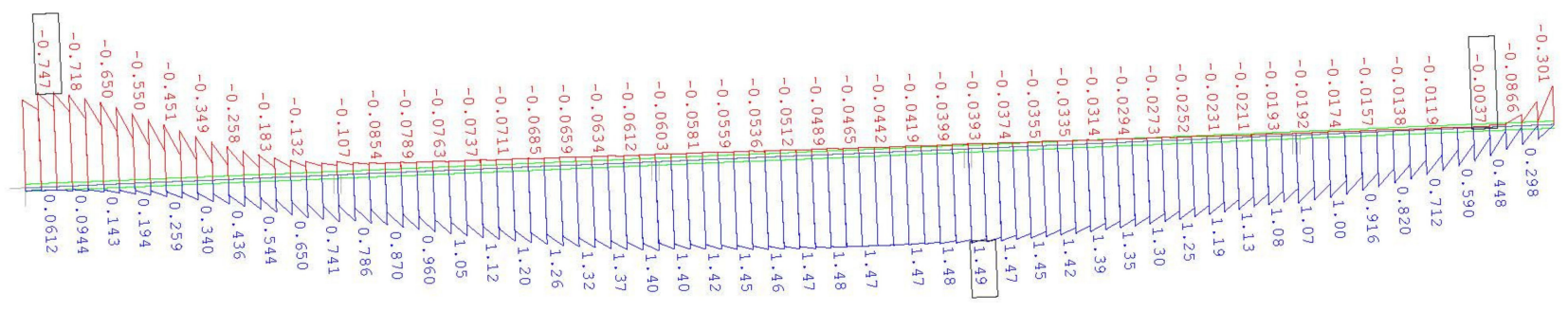

(a)

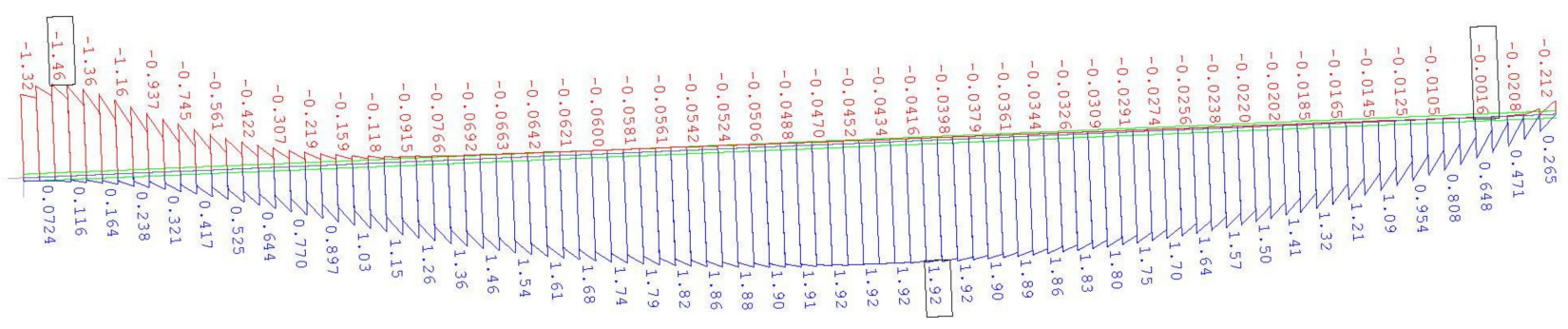

(b)

Figure A5. Characteristic values of bending moments $M(\mathrm{kNm})$ under the moving load q of class $\mathrm{C}$ in the right span: (a) Outer girder; (b) inner girder. 


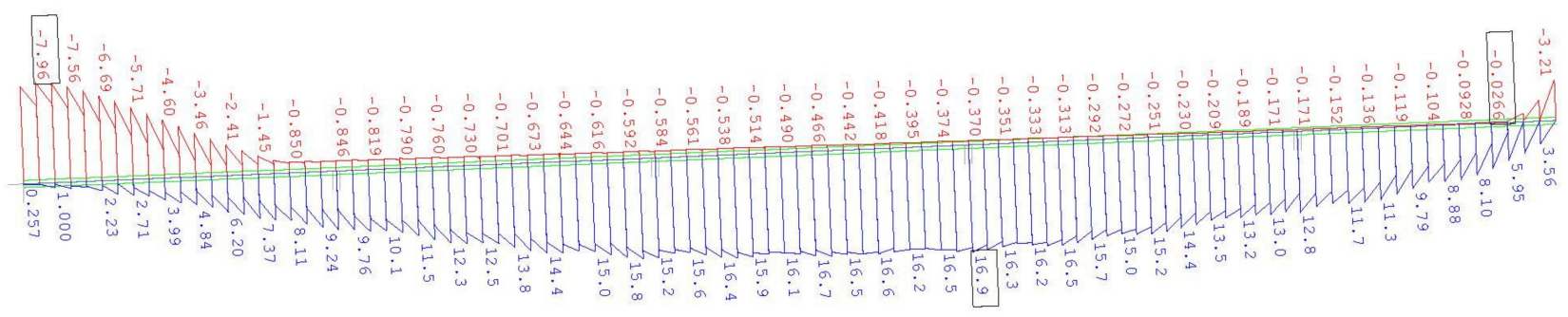

(a)

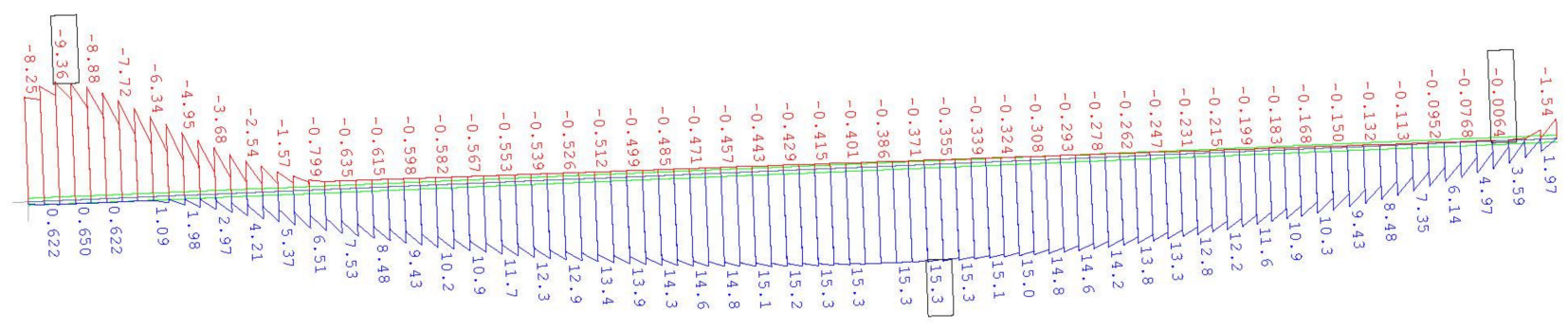

(b)

Figure A6. Characteristic values of bending moments $M(\mathrm{kNm})$ under the moving load $\mathrm{K}$ of class $\mathrm{C}$ in the right span: (a) Outer girder; (b) inner girder.

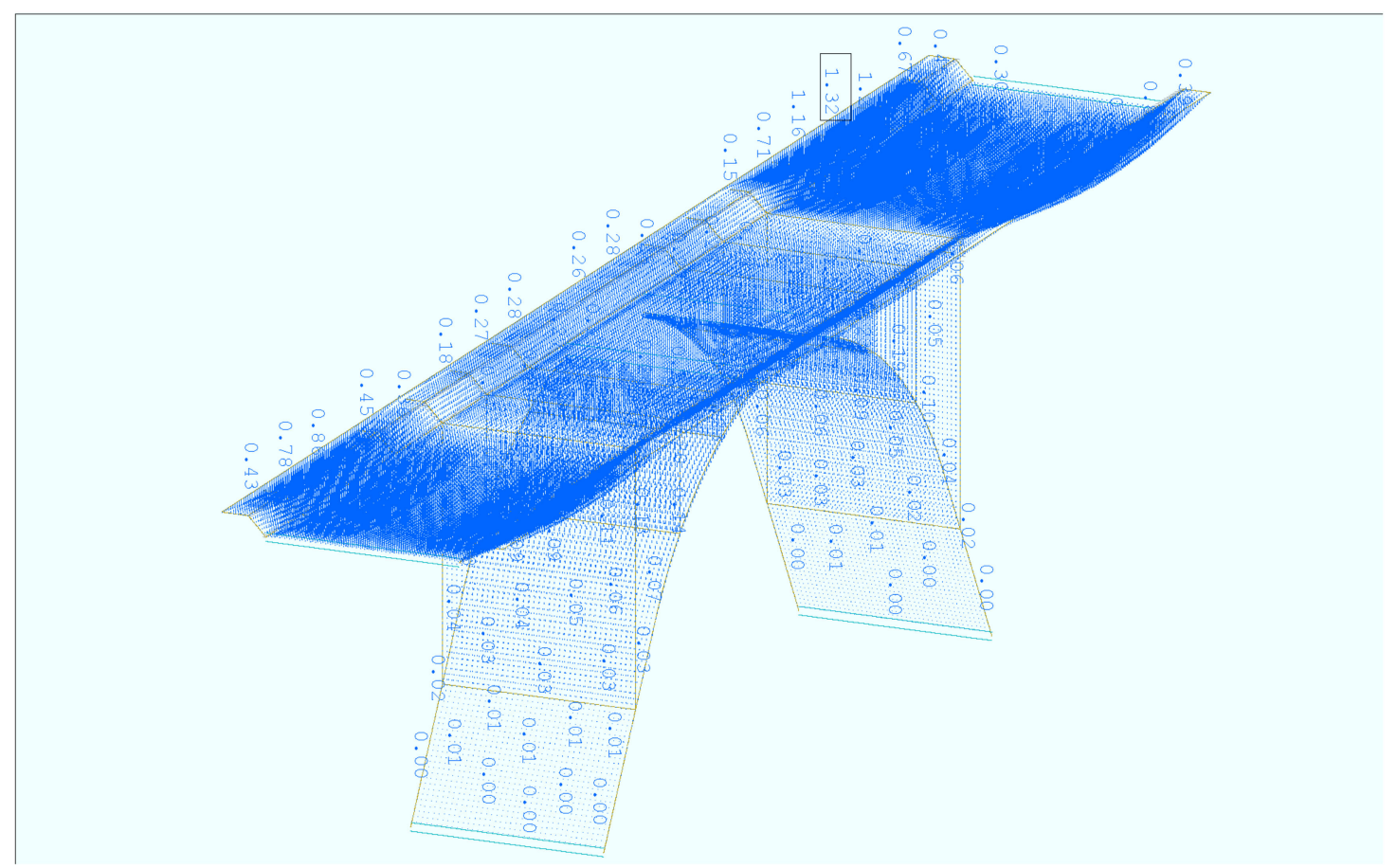

(a)

Figure A7. Cont. 


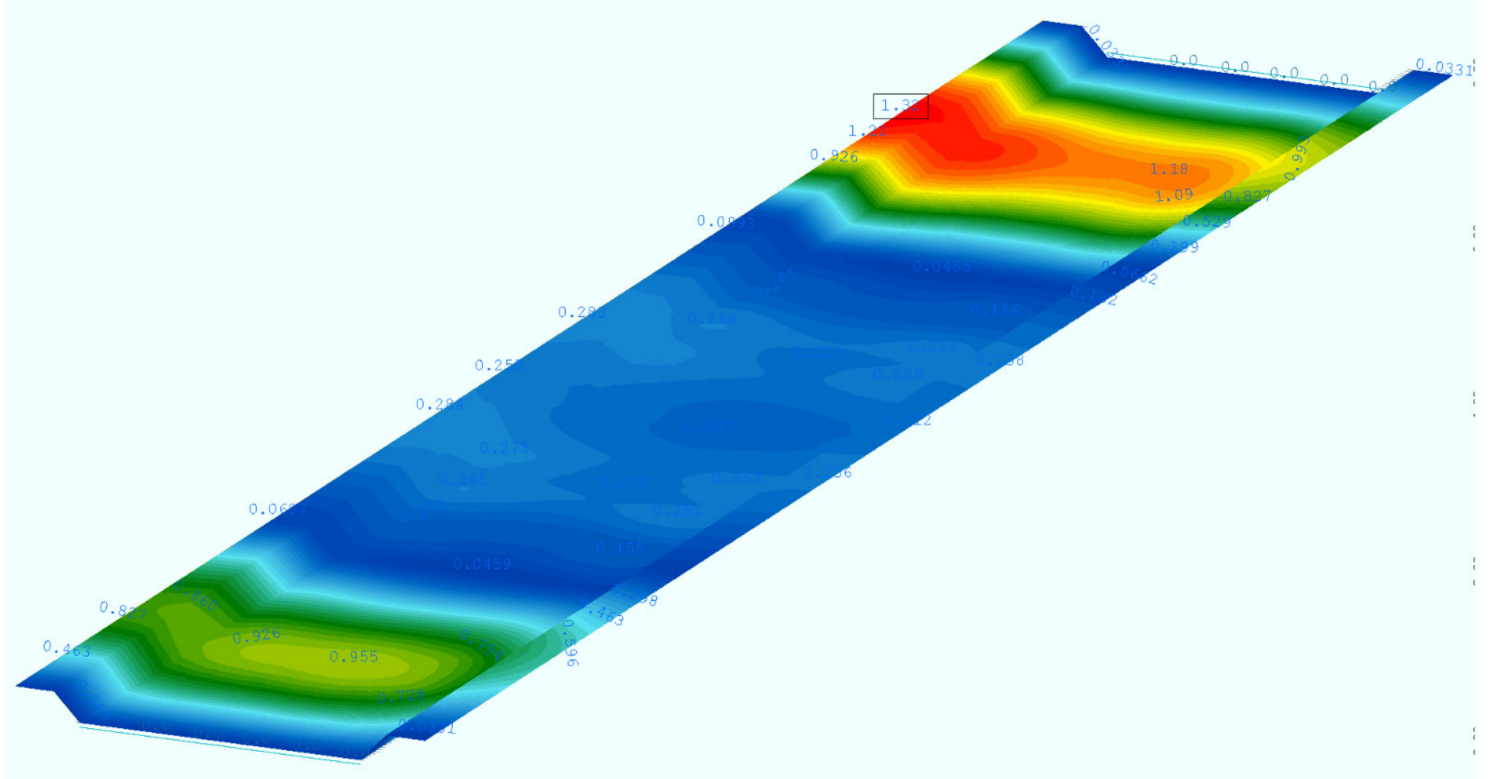

(b)

Figure A7. Extreme displacement $f(\mathrm{~mm})$ under the SLS combination of traffic loadings class C according to PN-S-10030 [56] standard: (a) 3 D structure view; (b) displacement map on the deck slab.

\section{References}

1. Chen, B.; Su, J.; Lin, S.; Chen, G.; Zhuang, Y.; Tabatabai, H. Development and application of concrete arch bridges in China. J. Asian Concr. Fed. 2017, 3, 12-19. [CrossRef]

2. Radić, J.; Kindij, A.; Mandić, A. History of Concrete Application in Development of Concrete and Hybriad Arch Bridges. In Proceedings of the Chinese-Croatian Joint Colloquium on Long Arch Bridges, Brijuni Islands, Croatia, 10-14 July 2008; Radić, J., Chen, B., Eds.; SECON HDGK: Zagreb, Croatia, 2008; Volume LONG ARCH, pp. 9-118.

3. Omar, T.; Nehdi, M. Condition Assessment of Reinforced Concrete Bridges: Current Practice and Research Challenges. Infrastructures 2018, 3, 36. [CrossRef]

4. Paulík, P.; Bačuvčík, M.; Brodňan, M.; Koteš, P.; Vičan, J. Reconstruction of the Oldest Reinforced Concrete Bridge in Slovakia in Krásno nad Kysucou. Procedia Eng. 2016, 156, 334-339. [CrossRef]

5. Witzany, J.; Zigler, R. Rehabilitation Design of a Historic Concrete Arch Bridge in Prague from the Early 20th Century. J. Perform. Constr. Facil. 2020, 34, 04020056. [CrossRef]

6. Hellebois, A.; Espion, B. Concrete properties of a 1904 Hennebique reinforced concrete viaduct. WIT Trans. Built Environ. 2011, 118, 589-600. [CrossRef]

7. Sena-Cruz, J.; Ferreira, R.M.; Ramos, L.F.; Fernandes, F.; Miranda, T.; Castro, F. Luiz bandeira bridge: Assessment of a historical reinforced concrete (RC) bridge. Int. J. Archit. Herit. 2013, 7, 628-652. [CrossRef]

8. Wolert, P.J.; Kolodziejczyk, M.K.; Stallings, J.M.; Nowak, A.S. Non-destructive Testing of a 100-Year-Old Reinforced Concrete Flat Slab Bridge. Front. Built Environ. 2020, 6, 1-12. [CrossRef]

9. Czaderski, C.; Motavalli, M. 40-Year-old full-scale concrete bridge girder strengthened with prestressed CFRP plates anchored using gradient method. Compos. Part B Eng. 2007, 38, 878-886. [CrossRef]

10. Pettigrew, C.S.; Barr, P.J.; Maguire, M.; Halling, M.W. Behavior of 48-Year-Old Double-Tee Bridge Girders Made with Lightweight Concrete. J. Bridg. Eng. 2016, 21, 04016054. [CrossRef]

11. Gebauer, J.; Harnik, A.B. Microstructure and composition of the hydrated cement paste of an 84 year old concrete bridge construction. Cem. Concr. Res. 1975, 5, 163-169. [CrossRef]

12. Papé, T.M.; Melchers, R.E. The effects of corrosion on 45-year-old pre-stressed concrete bridge beams. Struct. Infrastruct. Eng. 2011, 7, 101-108. [CrossRef]

13. Dasar, A.; Hamada, H.; Sagawa, Y.; Yamamoto, D. Deterioration progress and performance reduction of 40-year-old reinforced concrete beams in natural corrosion environments. Constr. Build. Mater. 2017, 149, 690-704. [CrossRef]

14. Khan, I.; François, R.; Castel, A. Structural performance of a 26-year-old corroded reinforced concrete beam. Eur. J. Environ. Civ. Eng. 2012, 16, 440-449. [CrossRef]

15. Shu, J.; Bagge, N.; Nilimaa, J. Field Destructive Testing of a Reinforced Concrete Bridge Deck Slab. J. Bridg. Eng. 2020, $25,04020067$. [CrossRef]

16. Turker, T. Structural evaluation of Aspendos (Belkis) Masonry Bridge. Struct. Eng. Mech. 2014, 50, 419-439. [CrossRef] 
17. Orlando, M.; Spinelli, P.; Vignoli, A. Structural analysis for the reconstruction design of the old bridge of Mostar. Adv. Archit. 2003, 15, 617-626.

18. Domede, N.; Sellier, A.; Stablon, T. Structural analysis of a multi-span railway masonry bridge combining in situ observations, laboratory tests and damage modelling. Eng. Struct. 2013, 56, 837-849. [CrossRef]

19. Pipinato, A.; Modena, C. Structural Analysis and Fatigue Reliability Assessment of the Paderno Bridge. Pract. Period. Struct. Des. Constr. 2010, 15, 109-124. [CrossRef]

20. Cardinale, G.; Orlando, M. Structural Evaluation and Strengthening of a Reinforced Concrete Bridge. J. Bridg. Eng. 2004, 9, 35-42. [CrossRef]

21. Richard, B.; Epaillard, S.; Cremona, C.; Elfgren, L.; Adelaide, L. Nonlinear finite element analysis of a 50 years old reinforced concrete trough bridge. Eng. Struct. 2010, 32, 3899-3910. [CrossRef]

22. Zhang, J.; Li, C.; Xu, F.; Yu, X. Test and Analysis for Ultimate Load-Carrying Capacity of Existing Reinforced Concrete Arch Ribs. J. Bridg. Eng. 2007, 12, 4-12. [CrossRef]

23. Lubowiecka, I.; Armesto, J.; Arias, P.; Lorenzo, H. Historic bridge modelling using laser scanning, ground penetrating radar and finite element methods in the context of structural dynamics. Eng. Struct. 2009, 31, 2667-2676. [CrossRef]

24. Lõhmus, H.; Ellmann, A.; Märdla, S.; Idnurm, S. Terrestrial laser scanning for the monitoring of bridge load tests-Two case studies. Surv. Rev. 2018, 50, 270-284. [CrossRef]

25. Valença, J.; Puente, I.; Júlio, E.; González-Jorge, H.; Arias-Sánchez, P. Assessment of cracks on concrete bridges using image processing supported by laser scanning survey. Constr. Build. Mater. 2017, 146, 668-678. [CrossRef]

26. Riveiro, B.; González-Jorge, H.; Varela, M.; Jauregui, D.V. Validation of terrestrial laser scanning and photogrammetry techniques for the measurement of vertical underclearance and beam geometry in structural inspection of bridges. Measurement 2013, 46, 784-794. [CrossRef]

27. Binczyk, M.; Kalitowski, P.; Szulwic, J.; Tysiac, P. Nondestructive Testing of the Miter Gates Using Various Measurement Methods. Sensors 2020, 20, 1749. [CrossRef] [PubMed]

28. Ziolkowski, P.; Szulwic, J.; Miskiewicz, M. Deformation Analysis of a Composite Bridge during Proof Loading Using Point Cloud Processing. Sensors 2018, 18, 4332. [CrossRef] [PubMed]

29. Rashidi, M.; Mohammadi, M.; Sadeghlou Kivi, S.; Abdolvand, M.M.; Truong-Hong, L.; Samali, B. A Decade of Modern Bridge Monitoring Using Terrestrial Laser Scanning: Review and Future Directions. Remote Sens. 2020, 12, 3796. [CrossRef]

30. Ambroziak, A.; Haustein, E.; Niedostatkiewicz, M. Chemical, Physical, and Mechanical Properties of 95-Year-Old Concrete Built-In Arch Bridge. Materials 2020, 14, 20. [CrossRef]

31. Lockemann, T. Elbing; Deutscher Architectur und Industrie-Verlag: Berlin-Halensee, Germany, 1926.

32. EN 12504-1 Testing Concrete in Structures_Part 1: Cored Specimens_Taking, Examining and Testing in Compression; CEN (European Committee for Standardization): Brussels, Belgium, 2009.

33. EN 12390-3 Testing Hardened Concrete. Compressive Strength of Test Specimens; CEN (European Committee for Standardization): Brussels, Belgium, 2019.

34. EN 12390-7 Testing Hardened Concrete—Part 7: Density of Hardened Concrete; CEN (European Committee for Standardization): Brussels, Belgium, 2019.

35. ISO (International Organization for Standardization) ISO 6892-1 Metallic Materials—Tensile Testing-Part 1: Method of Test at Room Temperature; ISO: Geneva, Switzerland, 2019.

36. Rules for the Construction and Maintenance of Road Bridges (Przepisy o Budowie i Utrzymaniu Mostów Drogowych); Pomorska Drukarnia Rolnicza, S.A.: Warszawa, Poland, 1926.

37. PN-B-195 Concrete and Reinforced Concrete Structures. Structural Analysis and Design; PKN (Polish Committee for Standardization): Warsaw, Poland, 1945.

38. Ambroziak, A. Application of elasto-viscoplastic Bodner-Partom constitutive equations in finite element analysis. Comput. Assist. Mech. Eng. Sci. 2007, 14, 405-429.

39. Brunarski, L.; Dohojda, M. An approach to in-situ compressive strength of concrete. Bull. Polish Acad. Sci. Tech. Sci. 2016, 64, 687-695. [CrossRef]

40. Domagała, L. Size Effect in Compressive Strength Tests of Cored Specimens of Lightweight Aggregate Concrete. Materials 2020, 13, 1187. [CrossRef]

41. EN 13791 Assessment of In-Situ Compressive Strength in Tructures and Precast Concrete Components; CEN (European Committee for Standardization): Brussels, Belgium, 2019.

42. Ambroziak, A.; Ziolkowski, P. Concrete compressive strength under changing environmental conditions during placement processes. Materials 2020, 13, 4577. [CrossRef]

43. Bestimmungen für die Ausführung von Bauwerken aus Eisenbeton; DAfStB (Deutscher Ausschuss für Stahlbeton): Berlin, Germany, 1916.

44. Deutsche Institut für Normung. DIN 1045:1925-09 Bestimmungen für Ausführung von Bauwerken aus Eisenbeton; Deutsche Institut für Normung: Berlin, Germany, 1925.

45. Hallauer, O. Die Entwicklung der Zusammensetzung von Beton für Wasserbauten. Mtteilungsblaetter Bundesanstalt für Wasserbaut. $1989,1988,39-56$. 
46. PN-B-195 Concrete and Reinforced Concrete Structures. Structural Analysis and Design; PKN (Polish Committee for Standardization): Warsaw, Poland, 1934.

47. EN 206:2013 + A1:2016 Concrete-Specification, Performance, Production and Conformity; CEN (European Committee for Standardization): Brussels, Belgium, 2016.

48. ACI 318-19 Building Code Requirements for Structural Concrete; ACI (American Concrete Institute): Farmington Hills, MI, USA, 2019; ISBN 9781641950565.

49. EN 1992-1-1 Eurocode 2: Design of Concrete Structures-Part 1-1: General Rules and Rules for Buildings; CEN (European Committee for Standardization): Brussels, Belgium, 2004.

50. ASTM C469M-14 Standard Test Method for Static Modulus of Elasticity and Poisson's Ratio of Concrete in Compression; ASTM International (American Society for Testing and Materials): West Conshohocken, PA, USA, 2014.

51. Żółtowski, K.J. Bridge over Vistula river in Kiezmark. Practical application of nonlinear shell FEM system. In Shell Structures: Theory and Applications; Pietraszkiewicz, W., Szymczak, C., Eds.; Taylor \& Francis Group: Abingdon, UK, 2005 ; pp. 521-525.

52. Siwowski, T.; Rajchel, M.; Kulpa, M. Design and field evaluation of a hybrid FRP composite—Lightweight concrete road bridge. Compos. Struct. 2019, 230, 111504. [CrossRef]

53. Siwowski, T.; Wysocki, A. Horizontal Rotation via Floatation as an Accelerated Bridge Construction for Long-Span Footbridge Erection: Case Study. J. Bridg. Eng. 2015, 20, 05014014. [CrossRef]

54. Erdenebat, D.; Waldmann, D. Application of the DAD method for damage localisation on an existing bridge structure using close-range UAV photogrammetry. Eng. Struct. 2020, 218, 110727. [CrossRef]

55. Skokandić, D.; Mandić Ivanković, A. Value of additional traffic data in the context of bridge service-life management. Struct. Infrastruct. Eng. 2020, 1-20. [CrossRef]

56. PN-S-10030 Bridges. Loads; PKN (Polish Committee for Standardization): Warsaw, Poland, 1985.

57. Malinowski, M.; Banas, A.; Jeszka, M.; Sitarski, A. Imaginative footbridge in Mikolajki, Poland. Stahlbau 2018, 87, 248-255. [CrossRef]

58. Malinowski, M.; Banas, A.; Cywiński, Z.; Jeszka, M.; Sitarski, A. Zur Wiedergeburt einer historischen Gitterbrücke. Stahlbau 2017, 86, 789-796. [CrossRef]

59. Imperatore, S.; Lavorato, D.; Nuti, C.; Santini, S.; Sguerri, L. Numerical Modeling of Existing RC Beams Strengthened in Shear with FRP U-sheets. In Proceedings of the 6th International Conference on FRP, Composites in Civil Engineering, CICE 2012, Rome, Italy, 13-15 June 2012; pp. 1-8.

60. El-Gamal, S.E. Finite Element Analysis of Concrete Bridge Slabs Reinforced with Fiber Reinforced Polymer Bars. J. Eng. Res. 2014, 11, 50. [CrossRef]

61. Ahmed, H.; La, H.M.; Tran, K. Rebar detection and localization for bridge deck inspection and evaluation using deep residual networks. Autom. Constr. 2020, 120, 103393. [CrossRef]

62. Erdogmus, E.; Garcia, E.; Amiri, A.S.; Schuller, M. A Novel Structural Health Monitoring Method for Reinforced Concrete Bridge Decks Using Ultrasonic Guided Waves. Infrastructures 2020, 5, 49. [CrossRef]

63. Asadi, P.; Gindy, M.; Alvarez, M. A Machine Learning Based Approach for Automatic Rebar Detection and Quantification of Deterioration in Concrete Bridge Deck Ground Penetrating Radar B-scan Images. KSCE J. Civ. Eng. 2019, 23, $2618-2627$. [CrossRef]

64. Kobaka, J.; Katzer, J.; Ponikiewski, T. A Combined Electromagnetic Induction and Radar-Based Test for Quality Control of Steel Fibre Reinforced Concrete. Materials 2019, 12, 3507. [CrossRef] [PubMed]

65. PN-EN 1992-1-1 Eurocode 2: Design of Concrete Structures-Part 1-1: General Rules and Rules for Buildings; PKN (Polish Committee for Standardization): Warsaw, Poland, 2008.

66. PN-S-10042 Bridges -Concrete, Reinforced Concrete and Prestressed Concrete Structures-Design; PKN (Polish Committee for Standardization): Warsaw, Poland, 1991.

67. Karas, S. Unique Hennebique Bridges in Lublin, Poland. Am. J. Civ. Eng. Archit. 2013, 1, 47-51. [CrossRef]

68. Banas, A.; Jankowski, R. Experimental and Numerical Study on Dynamics of Two Footbridges with Different Shapes of Girders. Appl. Sci. 2020, 10, 4505. [CrossRef]

69. Nowak, A.S.; Eom, J.; Sanli, A. Control of Live Load on Bridges. Transp. Res. Rec. J. Transp. Res. Board 2000, 1696, 136-143. [CrossRef]

70. Kilikevičius, A.; Bačinskas, D.; Jurevičius, M.; Kilikevičienè, K.; Fursenko, A.; Jakaitis, J.; Toločka, E. Field testing and dynamic analysis of old continuous truss steel bridge. Balt. J. Road Bridg. Eng. 2018, 13, 54-66. [CrossRef]

71. Podworna, M.; Klasztorny, M. Vertical vibrations of composite bridge/track structure/high-speed train systems. Part 3: Deterministic and random vibrations of exemplary system. Bull. Polish Acad. Sci. Tech. Sci. 2014, 62, 305-320. [CrossRef]

72. Law, S.S.; Zhu, X.Q. Dynamic behavior of damaged concrete bridge structures under moving vehicular loads. Eng. Struct. 2004, 26, 1279-1293. [CrossRef]

73. Biliszczuk, J.; Barcik, W.; Onysyk, J.; Toczkiewicz, R.; Tukendorf, A. The two largest Polish concrete bridges-Design and construction. Proc. Inst. Civ. Eng. Bridg. Eng. 2016, 169, 298-308. [CrossRef] 